\title{
A ciklussztratigráfia és az asztrokronológia korszerú módszerei és alkalmazásuk
}

A Milutin MILANKović-féle cikluselmélet matematikai alapjainak 100. évfordulójára.

\author{
VALLnER Zsolt ${ }^{1,2}$, BAJNAi Dávid ${ }^{3}$, PÁLFy József ${ }^{1,4}$
}

${ }^{1}$ Eötvös Loránd Tudományegyetem, Általános és Alkalmazott Földtani Tanszék, 1117 Budapest, Pázmány Péter sétány 1/C

${ }^{2}$ MTA ATOMKI, Izotóp Klimatológiai és Környezetkutató Központ, 4026 Debrecen, Bem tér 18/c

${ }^{3}$ Institut für Geologie und Mineralogie, Universität zu Köln, Zülpicher Str. 49b, 50674 Köln, Németország

${ }^{4}$ MTA-MTM-ELTE Paleontológiai Kutatócsoport, 1117 Budapest, Pázmány Péter sétány 1/C

Vallner Zsolt: email: zsolt.vallner@ gmail.com, ORCID: 0000-0002-6060-061X

Bajnai Dávid: email: david.bajnai@uni-koeln.de, ORCID: 0000-0002-4053-5056

Pálfy József: email: palfy@elte.hu, ORCID: 0000-0001-9686-1849

\section{Modern methods of cyclostratigraphy and astrochronology and their applications}

Abstract

To measure time is fundamental in geology for the temporal context of various Earth processes, whereas reconstruction of past climate changes is of outstanding relevance today. One hundred years ago in 1920, Milutin Milankovitch laid down the mathematical foundations of the theory of astronomically forced changes in insolation of Earth's surface. Cyclostratigraphy, the science of reading the stratigraphic record of Milankovitch cycles, i.e., climate cycles driven by periodic changes in orbital parameters, both provides a means to measure geological time (astrochronology) and to reconstruct paleoclimate. Although the scientific literature of this field has experienced exponential growth recently, the application of its modern methods has remained limited in Hungary. The aim of this review is, therefore, to encourage and facilitate that the Hungarian stratigraphic community embrace cyclostratigraphic methods. We review the basic characteristics of precession, obliquity, and eccentricity cycles and their climatic effects. We list the lithological, paleontological, physical, and geochemical proxies that can be utilized as time series for cyclostratigraphic studies. We present the steps of data pre-processing, spectral analysis, cycle identification and interpretation, together with modes of visualization and construction of age models. Among the available software solutions, the free Acycle is recommended as a versatile and user-friendly choice. We review the history of cyclostratigraphic studies in Hungary, with attention to the earlier methods applied. A summary of selected international case studies seeks to provide examples of works with a focus on astrochronology in order to improve the calibration of the time scale, studies of cyclic deposits that reflect different sedimentary environments, and milestone papers that demonstrate the close ties with palaeoclimatology. Hopefully, increasing use of cyclostratigraphic methods in Hungary will lead to significant advances in stratigraphy, sedimentology and paleoclimate research.

Keywords: Milankovitch cycles, spectral analysis, stratigraphy, orbital forcing, palaeoclimate

Összefoglalás

A geológia számára alapvető a Föld folyamatai időbeliségének feltárása, a földtörténeti múltbeli változások között pedig ma kitüntetett jelentőségú az éghajlatváltozások megismerése. Éppen száz éve, 1920-ban fektette le Milutin Milanković a Földet érő napsugárzás csillagászatilag meghatározott változásainak matematikai alapjait. A Milanković-ciklusok, vagyis a Föld pályaelemeinek periodikus változásai által vezérelt klímaciklusok üledékes kőzetekben rögzült nyomainak vizsgálatával foglalkozó ciklussztratigráfia egyszerre nyújt lehetőséget a földtörténeti idő mérésére (asztrokronológia), illetve a paleoklíma rekonstrukciójára. Bár a szakterület nemzetközi irodalma igen gyors ütemben gyarapodik, korszerú módszereinek alkalmazása Magyarországon mindeddig szúk körú maradt, ezért elterjedését ezzel a szemlével kívánjuk segíteni. Áttekintést adunk a precessziós, tengelyferdeségi és excentricitási ciklusokról és a Föld éghajlatára gyakorolt hatásukról. Számba vesszük azokat a litológiai, paleontológiai, fizikai és geokémiai adatsorokat, amelyek a ciklussztratigráfiai elemzés alapjául szolgálhatnak. Lépésról lépésre tárgyaljuk az adatelőkészítés, spektrálanalízis, ciklusazonosítás és -értelmezés menetét és az eredmények ábrázolásának módjait, melynek végén kormodell állítható elő Mindez különböző szoftverkörnyezetben történhet, például az ingyenesen elérhető és felhasználóbarát Acycle program segítségével. Képet adunk a magyarországi képződmények ciklussztratigráfiai vizsgálatának történetérôl, kitérve a korábban alkalmazott módszerekre. Rövid nemzetközi kitekintésünk példákat ad az időskála pontosítását segítő asztrokronológiai alkalmazásokról, különböző üledékképződési környezetek ciklusos képződményeinek vizsgálatáról és a paleoklimatológiával való elválaszthatatlan kapcsolatról. Nem kétséges, hogy a modern ciklusztratigráfia módszereinek bővülő hazai alkalmazása további izgalmas rétegtani, szedimentológiai és paleoklimatológiai eredményekhez vezethet.

Tárgyszavak: Milanković-ciklusok, spektrálanalízis, rétegtan, éghajlati kényszer, paleoklíma 


\section{Bevezetés}

Az üledékes kőzettestek litológiai, fizikai, geokémiai, paleontológiai és más sajátságai a rétegsoron belül gyakran ciklusos mintázattal rendelkeznek. A ciklussztratigráfia célja a rétegsorokban észlelhetô ciklusos változások felismerése, jellegének meghatározása, a ciklusos változásokat létrehozó folyamatok értelmezése elsősorban a rétegsorok korrelálása és képződésük idôtartamának meghatározása céljából (STRASSER et al. 2007). Ezek közül a legfontosabb a Milanković-ciklusok, vagyis a Föld pályaelem-változásaiból származó ciklusok vizsgálata (MilanKOVICH 1920). Azonban a ciklussztratigráfia tudományága ennél tágabb, hiszen számos olyan folyamat ismert, amely ciklusos rétegsorok kialakulásához vezet, pl. árapályciklusok (SzTANÓ 1995), El Niño-jelenség (KenNedy \& BRASSELl 1992) (1. táblázat). A ciklussztratigráfia segítségével nyerhetô koradatot, azaz az egyes rétegsorok által képviselt földtörténeti idô számított hosszát az asztrokronológia hasznosítja (WEEDON 2003, HinNov \& HiLGEN 2012, HinNov 2013). Mivel a kormeghatározás szempontjából a Milanković-ciklusok néhány tíz-százezer éves sávba esô periódusideje kiemelkedô jelentôségú, az asztrokronológia pedig az elmúlt évtizedekben rendkívül dinamikusan fejlődő tudományterületté vált, tanulmányunkban a fő figyelmet ennek szenteljük.

A ciklussztratigráfia több mint másfél évszázados múltra tekinthet vissza (ADHÉmAR 1842). CROLL (1864) és GILBERT (1895) ismerték fel először, hogy a Föld keringésének változásai befolyásolhatják a különböző szélességi körökön és a különböző évszakokban a Földet érô napsugárzás mennyiségét (STRASSER et al. 2007, HiLGEN 2010). Elméletük nem vált elfogadottá, mert azt számításokkal nem tudták alátámasztani. Évtizedekkel később, Milutin Milanković úttörố tanulmányában szolgált az első egzakt matematikai bizonyítékokkal (MiLANKOVICH 1920), így 2020-ban a Milanković-ciklusok centenáriumát is ünnepelhetjük (CVIJA-

1. táblázat. A ciklusos folyamatok időtartama és oka Table 1. Cycles in the geologic record

\begin{tabular}{l|l}
\multicolumn{1}{c|}{ Időskála } & \multicolumn{1}{c}{ Esemény } \\
\hline másodperc & $\begin{array}{l}\text { hullámzás } \\
\text { nap } \\
\text { hét } \\
\text { hónap } \\
\text { év } \\
10 \text { év } \\
1000 \text { év } \\
\text { szökőár- és vakárciklusok } \\
10.000 \text { év }\end{array}$ \\
100.000 év & $\begin{array}{l}\text { El Niño } \\
\text { napciklusok váltakozása } \\
\text { Dansgaard-Oeschger } \\
\text { ciklusok } \\
\text { Milanković-ciklusok } \\
\text { (precesszió, tengelyferdeség) } \\
\text { Milanković-ciklusok } \\
\text { (excentricitás) } \\
\text { nagy pályaelem ciklusok } \\
\text { (pl. 9 millió éves excentricitás) }\end{array}$ \\
\end{tabular}

NOVIC et al. 2020). Még teljesebben mutatja be MiLANKOVICH (1941) késôbbi, közismertebb múve és BACSÁK (1940) tanulmánya a matematikai módszerekkel megalapozott öszszefüggést a Föld pályaelemeinek változásai és a besugárzás megoszlása között (MAJOR 2006). Az elmélet ezek után egyre elfogadottabbá vált (SCHWARZACHER 1947, 1954; FisCHER 1964). A ciklusos mintázatot mutató üledékek vizsgálata az 1970-es években kapott újabb lendületet a mélytengeri DSDP-fúrások által szolgáltatott folytonos adatsorok következtében, melyek új empirikus bizonyítékát adták a negyedidőszaki klímaváltozásoknak (HAYs et al. 1976, IMBRIE \& IMBRIE 1979, IMBRIE \& IMBRIE 1980). A ciklussztratigráfia elnevezést FiscHER et al. (1990) vezette be. A szekvenciasztratigráfia megjelenése és térhódítása nyomán a ciklussztratigráfia hosszú időre összekapcsolódott ezzel a tudományterülettel (GOLDHAMMER et al. 1990, VAIL et al. 1991, NAISH \& KAMP 1997, STRASSER et al. 1999, SCHLAGER 2005). Leegyszerúsítve, a bevetté vált módszer szerint a kutatók megszámolták, hogy az adott rendû szekvenciából hány található az általuk vizsgált rétegsorban, majd ezzel a számmal osztották a rétegsor által képviselt, ismert vagy becsült időtartamot. Az eredmény megadta, hogy egy adott rendû szekvencia mennyi idôt reprezentál, és az így kapott periódusidő alapján párosították azt a valószínúsített ismert ciklusok, általában a Milanković-ciklusok egyikéhez.

A modern ciklussztratigráfia matematikai alapjait SCHWARZACHER $(1975,1992)$ fektette le, aki a korábban használt, bizonytalanabb módszer helyett jóval kvantitatívabb szemléletet vezetett be. A 2000-es évek elejére kialakuló modern ciklussztratigráfiához vezetô úton további fontos mérföldkövet jelentettek az EINSELE et al. (1991) és DE BoER \& SMITH (1994) által szerkesztett kötetek, melyekben a szerzôk a ciklusos üledékek leíró vizsgálatát alapozták meg. Az igazi áttöréshez azonban elsősorban a geomatematika és a számítástechnika fejlődésére volt szükség. A 90-es évektől kezdődően számos, a ciklikus rétegsorokból nyert idősorok matematikai, statisztikai vizsgálatára hivatott módszer fejlődött párhuzamosan, egymástól függetlenül is. Meghatározó jelentőségú a geokémiai módszerek fejlődése is, melyek eredményeiből pontos és nagy felbontású adatsorok képezhetôk. Ezek segítségével sok esetben a szabad szemmel látható ciklicitást nem mutató üledékekből is kimutathatóak ciklusok. Óriási előrelépést jelentett továbbá a csillagászati modellek folyamatos fejlődése és a ciklusokat létrehozó, irányító természetes folyamatok egyre pontosabb megismerése. A modern ciklussztratigráfia először a ciklikus változások meglétét azonosítja az üledékes rétegsorokban, majd ezeket frekvenciájuk és periódusuk segítségével statisztikai módszerekkel felelteti meg az ismert időtartamú ciklusoknak. Így abból, hogy egy adott frekvenciájú ciklus periódusa a rétegsorban hányszor ismétlődik és ennek a ciklusnak mi a periódusideje, kiszámítható a rétegsor képződésének időtartama. Ezt az eljárást alkalmazza az asztrokronológia, melynek a célja nem csupán a ciklusok létének bizonyítása, hanem az adott rétegsor által reprezentált időtartam meghatározása. A ciklussztratigráfiából levezetett asztrokronológia ezáltal a geológiai kormeghatározás fon- 
tos eszközévé vált. A ciklussztratigráfia továbbá alkalmas lehet az üledékbehordás mértékének és változásainak meghatározására, vagy más módszerekkel nem észlelhetô hiátusok kimutatására is (WEEDON 2003, HinNOV \& HILGEN 2012, HinNOV 2013).

A ciklussztratigráfia múvelésében új kihívást jelent a számítástechnika rohamos fejlődésének köszönhetően fejlesztett számos algoritmus és program közül a célnak legjobban megfelelőek és legmegbízhatóbbak kiválasztása, valamint a modern, matematikai alapokon nyugvó módszerek reprodukálhatóságának és eredményeik hitelességének bizonyítása. Ennek érdekében végezték el azt a kísérletet, melyben a szervezők mesterségesen generált adatsorokat adtak át a résztvevőknek, melyekbe zajjal terhelt ciklusos jeleket kódoltak (SINNESAEL et al. 2019). A résztvevők ezeket azt feltételezve kapták meg, hogy valódi, természetes rétegsorok adatairól van szó. A teszt arra a meglepó eredményre vezetett, hogy a megoldások átlaga minden esetben visszaadta az eredetileg kódolt jelet, valamint a kevésbé pontos megoldások hibája is elfogadhatónak bizonyult. A teszt kimutatta továbbá, hogy az eredmények pontossága nem függ számottevően a kutató tapasztaltságától. Tehát a ciklussztratigráfia gyorsan és hatékonyan tanulható, valamint az adott problémának megfelelő módszer alkalmazása esetén az egyes módszerek eredményei között nincs számottevő különbség.

Az utóbbi évtizedek során a ciklussztratigráfia önálló tudományterületté fejlődött, mely egyre inkább elfogadottá vált, és módszereit egyre szélesebb körben használják. Eredményei már eddig is rengeteg fontos új ismerethez vezettek, módszertana pedig továbbra is folyamatosan fejlődik. Mindezek ellenére Magyarországon mindeddig kevés tanulmány született a szakterület modern eszköztárának alkalmazásával. Dolgozatunk célkitǔzése ezért a ciklussztratigráfia és asztrokronológia alapjainak, korszerú módszereinek és alkalmazásainak összefoglalása, meghonosításuk ösztönzése érdekében.

\section{A Milanković-ciklusok}

Milanković-ciklusoknak nevezzük a Föld bizonyos pályaelem-paramétereinek periodikusan bekövetkező változását (WeEdon 2003, HinnOv \& HiLgen 2012, Hinnov 2013). A kb. 20-tól 405 ezer évig terjedô periódusú Milankovićciklusoknál léteznek nagyobb (akár 9 millió vagy 36 millió éves hosszúságú), ún. nagy pályaelem ciklusok (grand orbital cycles) (Martinez \& Dera 2015, Boulila 2019) és a Milanković-ciklusoknál kisebb, részben szintén pályaelemparaméterekhez köthető szub-Milanković-ciklusok is, de ezek jelentősége kisebb (WEEDON 2003), tárgyalásuk túlmutatna ennek a tanulmánynak a keretein (1. táblázat). A Föld három pályaeleme a Nap körüli keringési pálya ellipszisének lapultsága (excentricitása), a Föld forgási tengelyének ferdesége a keringés síkjához képest, valamint egy összetett mutató, a precesszió (1. ábra). A pályaelemek minden idôpillanatban számszerúsíthetőek a pályaelem- paraméterek révén. Ezek azonban nem állandóak, a Naprendszer égitestei közötti gravitációs kölcsönhatások következtében a földtörténet során folyamatosan, kváziperiodikusan változnak. Ahogy több pályaelem, úgy több pályaelem-paraméter ciklus is létezik, melyek periódusa eltérő hosszúságú, és relatív teljesítményük sem azonos. A Milanković-ciklusok alatt három ilyen ciklust értünk (WeEdon 2003, Hinnov \& Hilgen 2012, Hinnov 2013).

A Föld pályájának excentricitása, vagyis lapultsága a keringési elliptikus pálya középpontja és egyik fókuszpontja közötti távolságnak, valamint az ellipszishez tartozó fél nagytengely hosszának hányadosaként adható meg, kb. 0 0,07 között változik (1. ábra, A). A Milanković-ciklusokon belül két fó excentricitási ciklust, rövid és hosszú excentricitást különítünk el. A hosszú excentricitás a Jupiter és a Vénusz gravitációs kölcsönhatásából adódik. Mivel a Jupiter tömege a többi bolygóéhoz, így a Vénuszéhoz képest is óriási, így ennek a ciklusnak a 405 ezer éves periódusa kvázi állandónak tekinthetô legalább az elmúlt 250 millió évben. Ezzel szemben a rövid excentricitás periódusa kevésbé stabil, de jó közelítéssel 100 ezer év körül mozog. Ez a hossz azonban sokkal inkább több különböző relatív teljesítményú ciklus átlagának tekinthető, amelyek periódusideje ma 131 ezer, 124 ezer, 99 ezer és 95 ezer év, melyek közül csak a 124 ezer és 95 ezer év periódusú ciklusok jelentősek (LASKAR et al. 2004, HinNOv \& HiLgen 2012, HinNov 2013).

A tengelyferdeség paramétere az ekliptika síkjára állított merőleges és a forgástengely által bezárt szög (1. ábra, B). A Föld esetében ennek értéke 22-24,5 között változik, a ciklusait a Hold Föld körüli keringése stabilizálja. A tengelyferdeség nagy felbontás mellett szintén több kisebb ciklusból adódik össze, melyek közül teljesítmény tekintetében két, közelítóen 40 ezer éves ciklus emelkedik ki (LASKAR et al. 2004, HinNOv \& HiLGen 2012, HinNov 2013).

A precessziós index a korábban említetteknél összetettebb paraméter. A Föld forgástengelyének az ekliptikához viszonyított „,búgócsigaszerư” mozgása $(1$ ábra, $C$ ) ugyanúgy szerepet játszik benne, mint a Föld keringési pályájához tartozó nagytengely rotáló mozgása (1. ábra, $D)$. Előbbi az északi sarkról nézve az állócsillagokhoz képest óramutató járása szerint billeg körbe, míg utóbbi szintén az állócsillagokhoz képest óramutató járásával ellentétesen fordul körbe, minek következtében folyamatosan változik a Föld pályájának térbeli elhelyezkedése az állócsillagokhoz képest. Az így származtatható pályaelem-paraméter ciklusainak periódusidői ma jó közelítéssel 20 ezer év körül mozognak, a két domináns precessziós ciklus kb. 23,5 ezer és 19 ezer éves periódusidővel bír (LASKAR et al. 2004, HiNNOV \& HILGEN 2012, HINNOV 2013).

A Milanković-ciklusok régmúltra történő kiszámítása a csillagászati modellek egyenleteinek megoldása (astronomical solution) segítségével történik. Többfajta ilyen modell létezik, mert eltérő, hogy az egyes modellek milyen földtörténeti időtávlatban tekinthetőek megbízhatónak, valamint, hogy az egyes kutatók hány tényezőt és milyen tényezóket vesznek figyelembe a Föld egykori mozgásának rekonstruálásához és ezeket milyen pontosan képesek meg- 


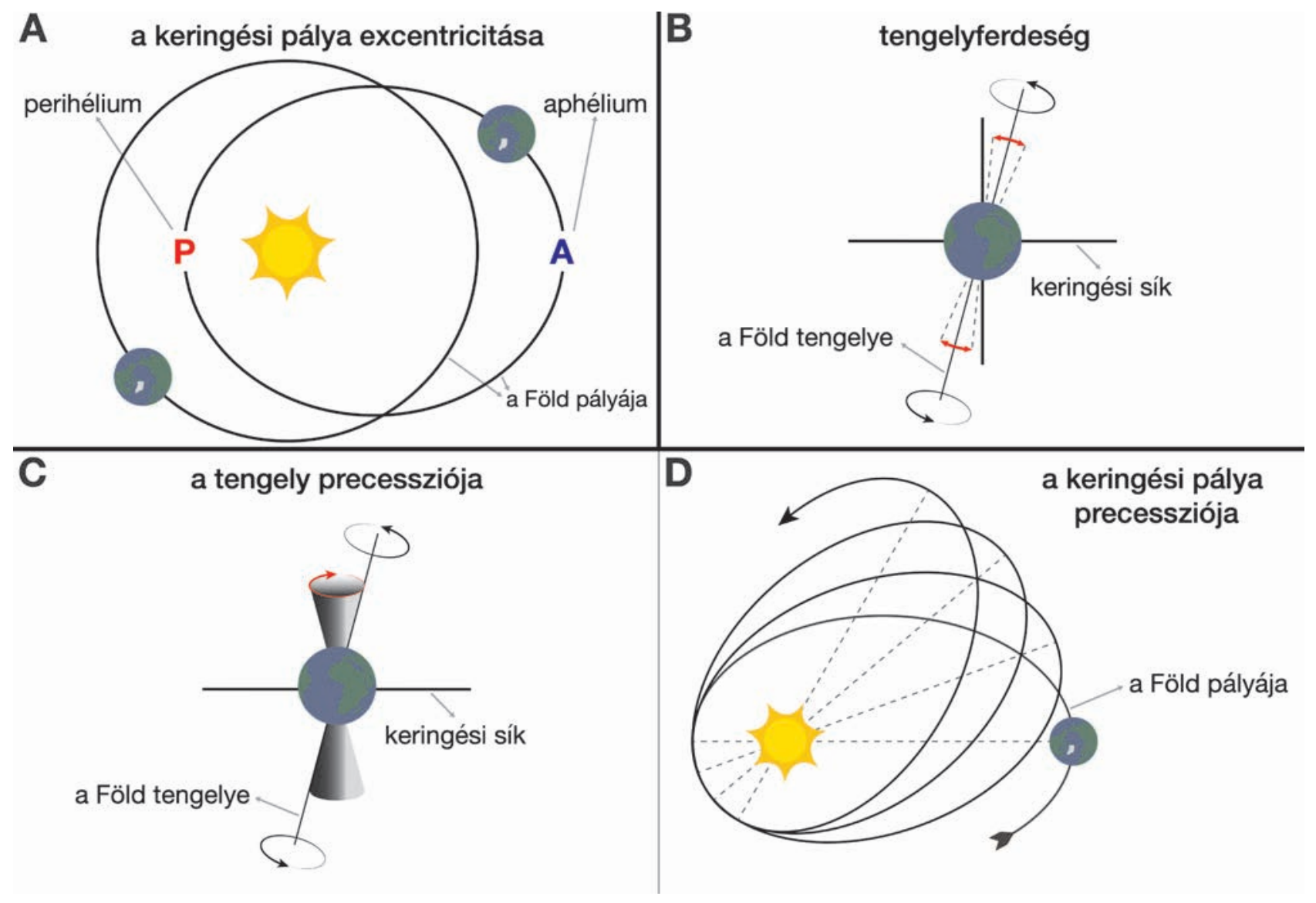

1. ábra. A Föld pályaelemei. (A) A földpálya excentricitása. A Föld keringési pályájának a Naphoz legközelebb eső pontját perihéliumnak (piros „P”-vel jelölve), a Naptól legtávolabb eső pontját pedig aphéliumnak (kék „A”-val jelölve) nevezzük. (B) A tengelyferdeség. A precesszió két komponense, (C) a forgástengely „búgócsigaszerü” mozgásához kapcsolódó komponens és (D) a földpálya nagytengelyének, vagyis az ekliptika síkjának mozgásához kapcsolódó komponens

Figure 1. The orbital parameters of Earth. (A) The eccentricity of the orbit. The point of the Earth's orbit closest to the Sun is called perihelion (marked by a red "P"), and the point farthest from the Sun is called aphelion (marked by a blue "A"). (B) The obliquity. The two components of precession are (C) the component related to the gyroscope-like motion of the axis and $(D)$ the component related to the motion of the semi-major axis of the orbit, i.e., the plane of the ecliptic

becsülni. A jelenleg legprecízebbnek tekintett és legszélesebb körben használt csillagászati modellekre a La2004 és La2010 rövidítéssel szokás hivatkozni (LASKAR et al. 2004, LASKAR et al. 2011). Az utóbbi időben több egyéb modell is megjelent, mint pl. a ZB17a vagy a ZB18a modell (ZEEBE 2017, ZEEBE \& LOURENS 2019).

A paraméterek és így a ciklusok is, a viszonylag stabil hosszú excentricitás kivételével, a jelenlegi modellekkel maximum 50 millió évre visszamenóleg rekonstruálhatóak teljes biztonsággal. Vagyis az utolsó 50 millió évre a csillagászati modellek nagy megbízhatósággal és pontossággal képesek kiszámítani a Milanković-ciklusokat, míg ennél korábbra az eredmények kevésbé tekinthetôek pontosnak, nagyobb a hiba lehetősége. Az 50 millió éves határ áttörését jelenleg sok tényező hátráltatja. Ilyen a bolygók forgása következtében bekövetkező kilapulás és dinamikus alakváltoztatás, a sarki jégsapkák megjelenése és elolvadása, illetve ezek bizonytalan ismerete a régmúltra nézve, az árapályjelenség és nem utolsósorban a Naprendszer kaotikus viselkedése (LASKAR et al. 2004, LASKAR et al. 2011, HiNNOV \& HILGEN 2012, HinNov 2013).

\section{A Milanković-ciklusok hatása az éghajlatra és az üledékes rendszerekre}

A Föld pályaelem-paramétereinek Milanković-ciklusok szerinti változása befolyásolja a Föld atmoszférájának tetejét elérô, a Napból származó besugárzás mennyiségét és térbeli eloszlását, ami az éghajlatra is hatással van. A pályaelemek változásainak klímára gyakorolt hatását nézve a tengelyferdeség szerepe érthetô meg a legegyszerúbben. Mindkét féltekén annak nyarán a Napból érkező sugarak meredekebb szög alatt esnek be a Földre, mint ugyanakkor az ellentétes féltekén, ahol ekkor épp tél van. Minél nagyobb a tengelyferdeség szögértéke, annál nagyobb lesz a különbség az északi és déli féltekére érkező napsugarak beesési szöge között az adott évszakban, ezáltal az évszakok közötti különbségek élesednek (2. ábra) (BERGER \& LOUTRE 1994).

Az excentricitás és a precesszió összekapcsolt módon hat a klímára (3. ábra). Mivel a Nap nem a Föld ellipszis alakú pályájának középpontjában, hanem az egyik gyújtópontjában helyezkedik el, ezért a Föld keringése során napközeli (perihélium) és naptávoli (aphélium) helyzetbe kerül (1. ábra). Az ellipszis alakú pálya lapultsága, vagyis az ex- 


\section{A kis tengelyferdeség esetén:}

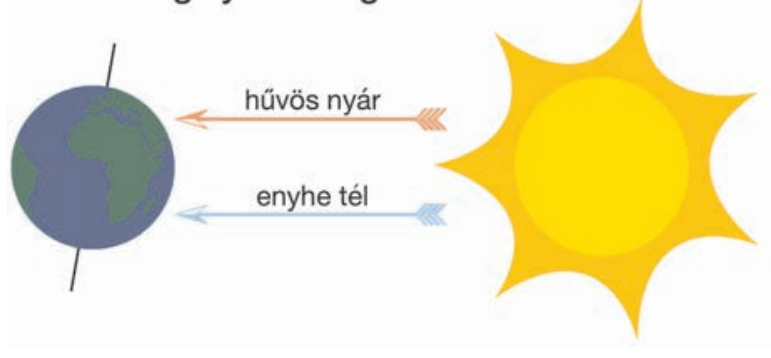

2. ábra. A tengelyferdeség hatása a klímára

Figure 2. Impact of Earth's obliquity on the climate

\section{B nagy tengelyferdeség esetén:}

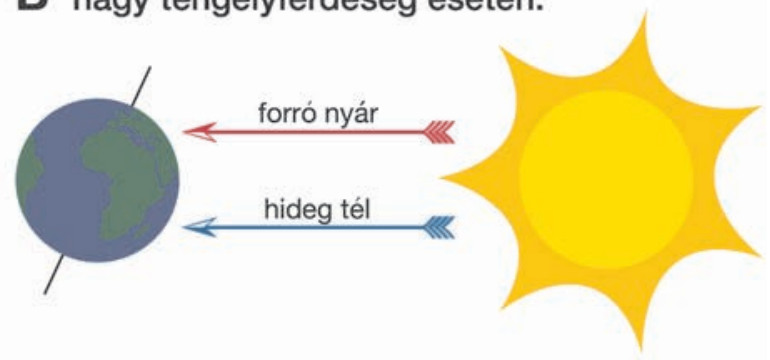

centricitása befolyásolja a Nap-Föld távolság mértékét a Föld keringése során, így a peri- és aphélium idején is. A besugárzás erôssége a Nap-Föld távolságtól függ. Minél kisebb a távolság, annál erősebb a besugárzás. A precesszió azt befolyásolja, hogy az adott féltekén melyik évszak következik be perihéliumban és aphéliumban. Ez azért fontos, mert például, ha az északi félteke nyara perihéliumban következik be, akkor a nyár melegebb, „nyáriasabb” lesz, míg ugyanekkor a déli félteke tele enyhébb, kevésbé lesz „télies” (3. ábra, A). Ugyanez történik megfordítva a naptávoli pozícióban is. Ha az északi féltekén a nyár napközelben következett be, akkor naptávolban tél lesz, míg a déli félgömbön nyár. Az északi féltekén a Nap távolsága miatt a tél hidegebb, „téliesebb” lesz, míg a déli félteke nyara húvös, kevésbé „nyárias” lesz. Pontosan fél precessziós ciklussal (ami jelenleg kb. 11 ezer év) később az északi félteke tele fog bekö-

nagy excentricitás esetén:
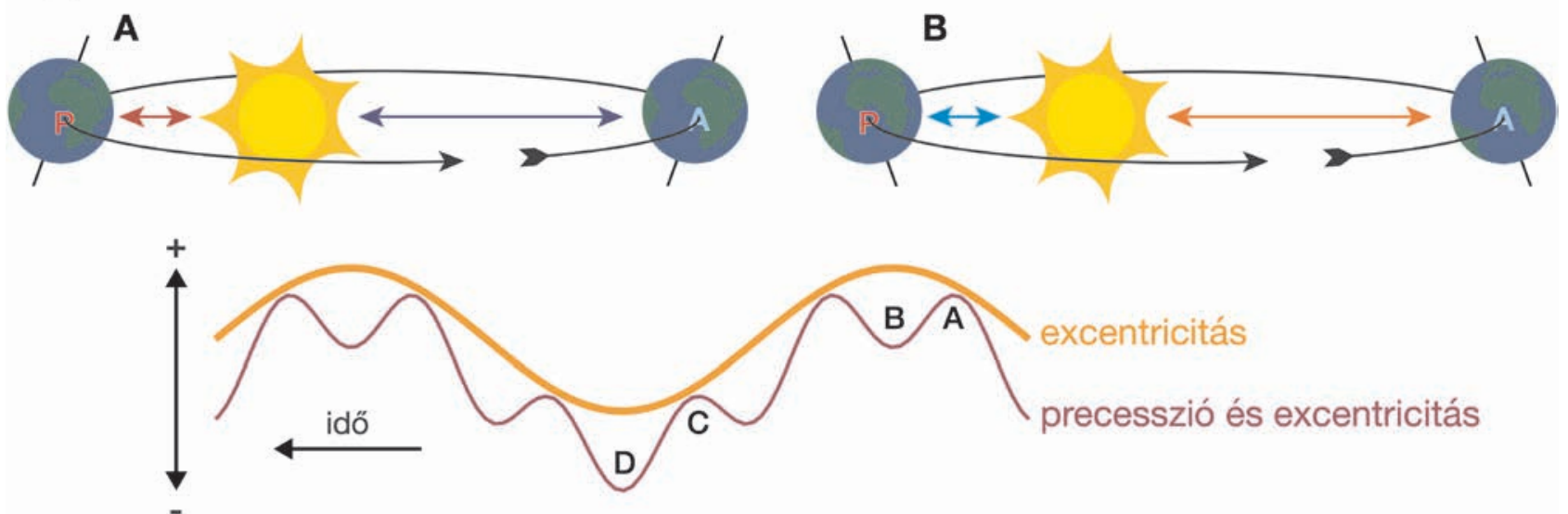

kis excentricitás esetén:
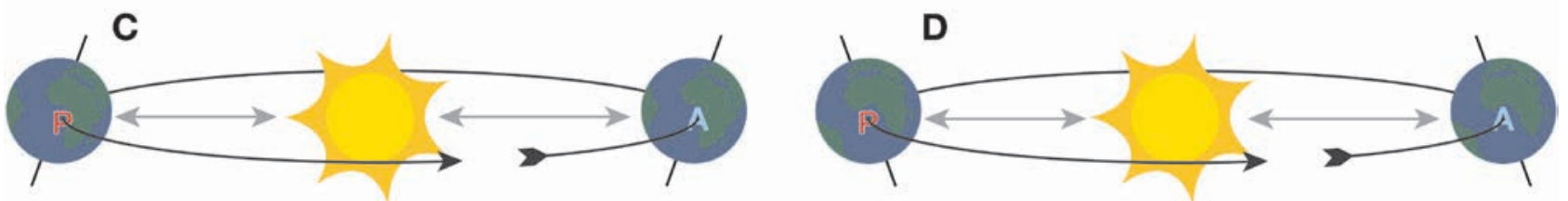

3. ábra. Az excentricitás és a precesszió együttes hatása az éghajlatra. A precessziótól függ, hogy melyik féltekén milyen évszakban éri el a Föld a peri- (piros „P”vel jelölve), vagy aphéliumi (kék „A”-val jelölve) helyzetet, míg ezekben a pontokban Nap-Föld távolságot az excentricitás határozza meg. Az A) esetben az északi félteke nyara a perihéliumban, tele az aphéliumban van, ami forróbb nyarat és hidegebb telet eredményez. A B) esetben az északi félteke tele a perihéliumban, nyara pedig az aphéliumban következik be, ami enyhébb télhez és hüvösebb nyárhoz vezet. A C) és D) esetekben, kis excentricitás idején, a közel kör alakú pálya miatt nincsen nagy különbség a Nap-Föld távolságában aphélium és perihélium között. Ekkor az évszakok nyárias és télies vonásainak sem erősitésére, sem pedig tompitására nem kerül sor (MARTínEZ-BraCERAS et al. 2017 alapján

Figure 3. The combined effect of eccentricity and precession on the climate. The precession controls both the hemisphere and the season at the time when the Earth reaches the peri-(marked by a red „P”) or aphelion (marked by a blue „A"), whereas the eccentricity determines the Sun-Earth distance at these points. In case A), the summer of the northern hemisphere is in the perihelion and winter is in the aphelion, which results in a hotter summer and a colder winter. In case B), the winter of the northern hemisphere occurs in the perihelion and the summer occurs in the aphelion, which leads to a milder winter and a cooler summer. In cases $C$ ) and D), at times of low eccentricity, due to the nearly circular orbit, there is no significant difference in the Sun-Earth distance between aphelion and perihelion. At such configuration, the summer and winter features of the seasons are neither strengthened nor dampened (Inspired by MARTINEZ-BRACERAS et al. [2017]) 
vetkezni a perihéliumban és az északi félteke nyara az aphéliumban (3. ábra, $B$ ). A hatások ekkor a két félgömbre nézve pont megfordulnak az előzőekben leírtakhoz képest. Minél nagyobb az excentricitás értéke, ezek a különbségek annál jobban kiéleződnek, annál nagyobb a precesszió hatásainak amplitúdója. Kis excentricitás esetén az évszakok közötti különbség alacsony (3. ábra, $C-D$ ). A két paraméter együttes, a klímára gyakorolt hatását nevezik szezonalitásnak is, hiszen tôlük függ, hogy a nyarak mennyire ,nyáriasak”, a telek pedig mennyire „téliesek”, azaz mennyire erős a kontraszt az egyes évszakok között (BERGER \& LOUTRE 1994, MARTínEZ-Braceras et al. 2017).

Összefoglalva, az excentricitás a Föld-Nap távolságot és így a besugárzás mértékét befolyásolja, a tengelyferdeség a besugárzás beesési szögét, így annak szélesség szerinti eloszlását határozza meg, a precesszió pedig a Föld pályájához képest az évszakok időzítését irányítja. A Milankovićciklusok vizsgálatakor figyelembe kell venni az adott rétegsor képződésének egykori földrajzi szélességét, mivel az excentricitás, a tengelyferdeség és a precesszió dominanciája a szélesség függvényében változik. Míg az alacsony szélességek precessziódomináltak, vagyis klímájukra a preceszszió és az excentricitás sokkal nagyobb hatással bír, addig a magasabb szélességek inkább a tengelyferdeségi ciklus által domináltak, ennek a ciklusnak sokkal nagyobb a hatása az éghajlatukra (BERGER \& LOUTRE 1994, WEEDON 2003, Hinnov \& Hilgen 2012, Hinnov 2013). Előfordulhat azonban, hogy az óceán és a légkör áramlásainak közvetítésével a tengelyferdeség dominanciája az alacsonyabb szélességek felé is lehúzódik (D’ARGENIO et al. 2004).

Mivel a pályaelemciklusok jelentôsen befolyásolják az éghajlatot, beleértve az éghajlati övek elrendeződését is, így áttételes hatással vannak az üledékképződést meghatározó számos paraméterre, amelyeknek köszönhetôen jelük megőrzôdhet az üledékes kőzetrétegsorokban. A Milankovićciklusok hatást gyakorolnak a légköri hőmérsékletre, illetve cirkulációs rendszerekre, ami szabályozza a víztömegek felszíni hőmérsékletét. Ezek a hatások továbbgyúrúznek az óceáni cirkulációs rendszerekre, és a szárazföldön is változásokat idéznek elő a csapadék mennyiségében és évszakos, valamint területi eloszlásában. Az éghajlat és a cirkulációs rendszerek megváltozása tükröződik többek között a folyók által szállított víz mennyiségében, a gleccserek jégtömegének mennyiségében, valamint a szelek erôsségében és irányában. Ezek a tényezôk, kiegészülve a felszíni növényborítottság változásaival, illetve a mállás intenzitásában és minőségében bekövetkező változásokkal, erősen befolyásolják az üledékgyújtőkbe érkező üledék mennyiségét és összetételét. A folyók által az üledékgyújtőkbe szállított édesvíz és tápanyag mennyisége, az evaporáció, valamint az atmoés hidroszféra kölcsönhatása vízkémiai változásokat idéz elő, amelyek megőrződhetnek a biogén és nem biogén eredetú üledékek elem- és izotópösszetételében, geokémiai jeleket hozva létre (STRASSER et al. 2007). Emellett ezek a változások a bioszférára is hatással vannak, befolyásolva egyebek közt a plankton és bentosz szervezetek karbonáttermelését és az elsődleges biológiai produkciót.
Fontos tényező továbbá az eusztatikus tengerszint változása, mely szintén kapcsolatban állhat a pályaelem ciklusokkal. Jégkorszakok idején a sarki jégsapkák, illetve a gleccserek jégtömegének változása, míg melegház periódusokban a magashegységi gleccserek olvadása és növekedése, az óceáni víztömegek hőtágulása és összehúzódása (STRASSER et al. 2007), valamint az akvifer-eusztázia (WENDLER et al. 2016) szabályozhatja ezt. Az üledékes és biológiai rendszerek tehát érzékenységüktől függốen rendkívül szerteágazó és összetett módokon ôrizhetik meg a Milanković-ciklusok jelét.

\section{A ciklussztratigráfiai vizsgálat menete}

A ciklussztratigráfiai vizsgálat megkezdése előtt tisztázandó kérdés a vizsgált rétegsor hozzávetőleges kora, ugyanis a csillagászati modellek által megszabott 50 millió éves határ miatt némileg más protokoll vonatkozik az ennél fiatalabb, illetve idősebb rétegsorokra (LASKAR et al. 2011, HinNOv 2013). Az 50 millió évnél idősebb szelvényekben is vizsgálható a Milanković-ciklusok megőrződése, azonban míg a kb. 50 millió évnél fiatalabb rétegsorok esetében ún. csillagászati kalibráció (astronomical tuning) is lehetséges és ezáltal a ciklusok segítségével számszerú kor is megadható, addig az ennél idősebb rétegsorok esetén csak ún. lebegó korskála (floating timescale) hozható létre (4. ábra). A csillagászati kalibráció alkalmazása során először célgörbét (target curve) választunk, ami lehet valamelyik csillagászati modell vagy ma már egyre gyakrabban a nem túl távoli múltra szintén pontosan kiszámítható besugárzási görbe. A rétegsorból kinyert adatsort a célgörbéhez hasonlítjuk. Többféle statisztikai módszer áll rendelkezésre a célgörbével való legjobb egyezés megállapítására vagy a megfeleló szintû egyezés hiányában a Milanković-ciklusok meglétének elvetésére. A célgörbe ismert korú pontjainak segítségével a vizsgált adatsor pontjaihoz számszerú kor kapcsolható. Ezzel szemben a lebegố korskála esetén csak az egyes pontok közötti időkülönbség, vagyis az üledékképződés időtartama számítható a ciklusok segítségével, amihez számszerú kor nem rendelhetô. Amennyiben egy pont kora független módszer (pl. radiometrikus kormeghatározás) segítségével ismert, ezáltal a lebegô korskála lehorgonyozásra kerül, akkor az idôkülönbségek segítségével minden pont kora kiszámítható, feltéve hogy folytonos rétegsorról van szó (WeEdon 2003, HinNov 2013). Mivel a módszertan a két esetben csak az utolsó lépésben tér el, ezért a következőkben mindaddig együtt mutatjuk be az 50 millió évnél idősebb és fiatalabb rétegsorok feldolgozását.

\section{Vizsgálható adatsorok és adatelókészítési múveletek}

Az éghajlat Milanković-ciklusokhoz kapcsolható kváziperiodikus változásai nemcsak a rétegek vastagságának és összetételének változásaiban, hanem az egyes klímaelemek változására utaló jellegek, ún. klímaproxyk jelében is meg- 


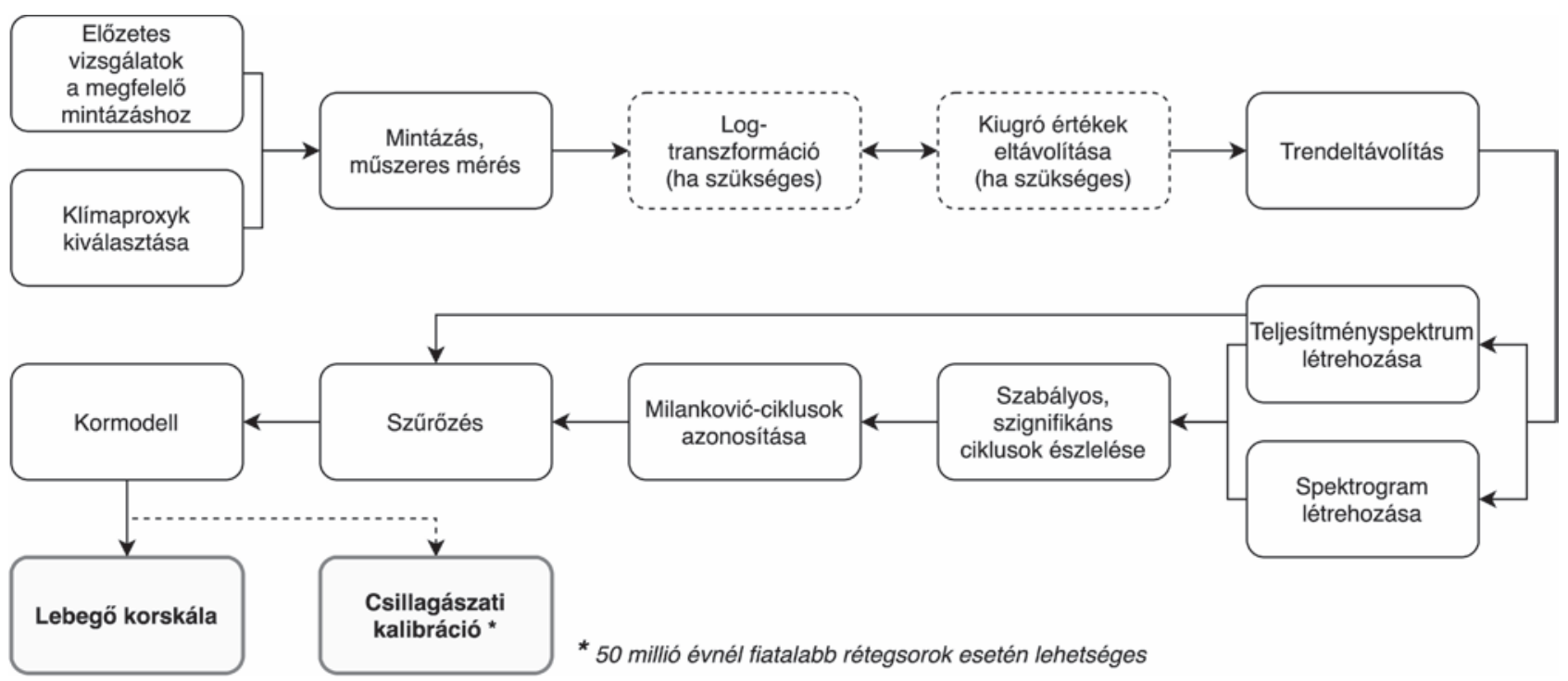

4. ábra. A ciklussztratigráfiai és asztrokronológiai vizsgálatok folyamatábrája. Melléktermékként meghatározható az üledéklerakódási sebesség és annak változásai Figure 4. Flowchart of cyclostratigraphic and astrochronological studies. The sedimentary rate and its changes can be determined as a by-product

őrődhetnek. A klímaproxyk olyan változók, melyek az egykori éghajlat bizonyos tényezőire (pl. hőmérséklet, csapadék stb.) engednek közvetett módon következtetni (WEEDON 2003, MARTINEZ 2018, Li et al. 2019b).

A ciklussztratigráfiában számos klímaproxyt és egyéb, az üledékképződési folyamatokkal szoros kapcsolatban álló proxyt használnak. Ilyen a litofácies, a rétegvastagság, a kőzet színe és fényessége, a szemcseméret, a porozitás és a permeabilitás, az agyag vagy por mennyisége, a természetes gammasugárzás, az agyagfrakció ásványos összetétele, a titanomagnetit tartalom, a mágneses szuszceptibilitás, a Fetartalom, a diagenetikusan inert, elsősorban agyagokhoz kapcsolódó elemek, pl. K, Rb vagy Ti, a ritkaföldfémek, a Mo-tartalom, az Al/Ti arány, a nem karbonát frakció menynyisége, az U, Th, Th/U, Th/K arány, a redox-érzékeny elemek, pl. Mn, a Si és a szerves eredetú széntartalom, a szén és oxigén stabilizotóp-összetétele ( $\delta^{13} \mathrm{C}$ és $\left.\delta^{18} \mathrm{O}\right)$, a $\mathrm{Sr}$ és $\mathrm{Mg}$, a karbonáttartalom, a palinológiai adatok, a mikrofosszília közösségek és a mikrofosszíliák gyakorisága, valamint az egyéb ősmaradvány, akár nyomfosszília közösségek. A felsoroltak közül több proxy is egy másikkal összefüggésben változik, pl. a természetes gamma jele utal a K-tartalomra, ami viszont az agyagtartalommal korrelálhat, így az egyes proxyk között átfedés tapasztalható. A vizsgált proxyk kiválasztásakor tehát fontos annak figyelembevétele, hogy az egyes proxyk milyen környezeti folyamat(ok)ra reagálnak (WeEdon 2003, D'Argenio et al. 2004, WestPhal et al. 2010, MARTinez 2018, Li et al. 2019b). Emellett fontos annak felismerése és kiszúrése is, ha egy proxyt diagenetikus változás ért, és emiatt nem használható megbízhatóan.

A klímaproxyk időbeli változásait idősorokon (time-series) keresztül vizsgálhatjuk. Klasszikus értelemben idősornak csak az idő függvényében tanulmányozott változók értékei nevezhetők, de hagyományosan a ciklussztratigráfiában ez a térfüggő adatsorok elnevezésére is használatos.
Az idôsorban nem csak a mintapont saját értéke lényeges, hanem annak térbeli és/vagy időbeli függése is. Az idősorokat gyakran jelként emlegetik, sokszor azonban a jel fogalmát csak az idősorok szabályos komponenseire használják. Az idősorok jellemzően szabályos és szabálytalan komponensekből és/vagy zajból állnak. A ciklussztratigráfia számára csupán a szabályos komponens keresése a cél (WEEDON 2003).

A ciklussztratigráfia szempontjából matematikai és geológiai értelemben is két fó jeltípust különíthetünk el az idôsorokon belül. Folytonos jel (continuous signal) esetében a mért változó időben folyamatos, tetszőleges ponthoz tartozik érték, azaz a változó az idő vagy a tér (azaz cm vagy m értékkel kifejezett rétegtani helyzet) függvényében ábrázolható. Ilyen jelet szolgáltatnak pl. a különféle geokémiai mérések eredményei, ahol a mintavételi távolságot a kutató határozza meg. Diszkrét jel (discrete signal) esetében a mért változó időben nem folytonos. Diszkrét jelet szolgáltat például az egymást követô rétegek vastagsága; ebben az esetben az egyik tengelyen a rétegvastagság, míg a másikon a rétegek száma (a rétegsorban felfelé haladva egyesével számozzuk óket) ábrázolandó. A mintavételi távolságot ilyenkor az egyes rétegek vastagsága szabja meg, hiszen minden mintapont maga az adott réteg. Ebben az esetben nem valósulhat meg, hogy a mintavételi távolság minden mintapont között ugyanakkora, vagyis egyenközú legyen (WEEDON 2003). Litofácies-elemzés útján meghatározott kategóriák alkalmazásával is előállítható a kőzetminőséget leíró diszkrét jel, amire éghajlatvezérelt vízmélységváltozásokat tükröző tavi üledékek vizsgálata szolgáltat példát (OLSEN \& KENT 1996).

Bár a nem egyenközú idősorok elemzésére is vannak megfelelő matematikai módszerek (pl. interpoláció vagy Lomb-Scargle periodogram használata (LOMB 1976, SCARGLE 1982)), a ciklussztratigráfiában mégis általában az egyenközú idősorok használata a bevett (WEEDON 2003, Li et al. 2019a). 
A mintavételezés megkezdése előtt, az információvesztés elkerülése végett fontos a Nyquist-frekvencia figyelembevétele. Definíciója szerint a Nyquist-frekvencia az adott mintaköz mellett az idősorból kimutatható legnagyobb frekvencia, ami, mivel a periódus a frekvencia reciproka, egyben meghatározza a kimutatható legrövidebb periódust (WhitTAKER 1915, NyQuist 1928, Kotelnikov 1933, SHANNON 1949). Mivel egy ciklus azonosításához hullámhoszszonként minimum két mintapont szükséges (5. ábra), ezért a Nyquist-frekvencia $\left(\mathrm{f}_{\mathrm{Ny}}\right)$ hullámhossza kétszerese a mintavételi távolságnak $(\Delta \mathrm{d})$, vagyis a Nyquist-periódus $\left(\mathrm{p}_{\mathrm{Ny}}\right)$ kétszer olyan hosszú lesz, mint a választott mintaköz által képviselt üledékképződési időtartam:

$$
\begin{aligned}
& p_{N y}=2 \times \Delta d \\
& f_{N y}=\frac{1}{2 \times \Delta d}
\end{aligned}
$$

A gyakorlatban a mintegy 20 ezer éves periódusidejú precesszió kimutatásához a mintaköznek kevesebb mint 10 ezer évet kell átfognia. Mivel a Milanković-ciklusok periódusideje a földtörténet során változik, figyelembe kell venni a mintázni kívánt rétegsor korát és az annak megfelelô precessziós ciklus hosszát. Mivel a rétegsor néhány 10 ezer éves pontosságú időbeli felbontását éppen a ciklussztratigráfiával szeretnénk elérni, gyakori probléma, hogy nehéz előre megmondani, mekkora vastagság képviselhet kb. 10 ezer évet a vizsgált képződményben. Ilyenkor független adatok, mint pl. rendelkezésre álló radiometrikus korok, szekvenciasztratigráfia vagy egyéb rétegtani módszerek segítségével próbáljuk megbecsülni az ideális mintaközt (WEEDON 2003, SinNESAEL et al. 2019).

A Nyquist-frekvencia által megszabottnál nagyobb mintavételi közök esetében a legnagyobb frekvenciájú ciklus, azaz Milanković-ciklusok esetében a precesszió, kimutathatatlanná válik. Ugyanakkor, ha pontosan a Nyquist-frekvencia által megszabott mintaközt használjuk, vagyis perió-

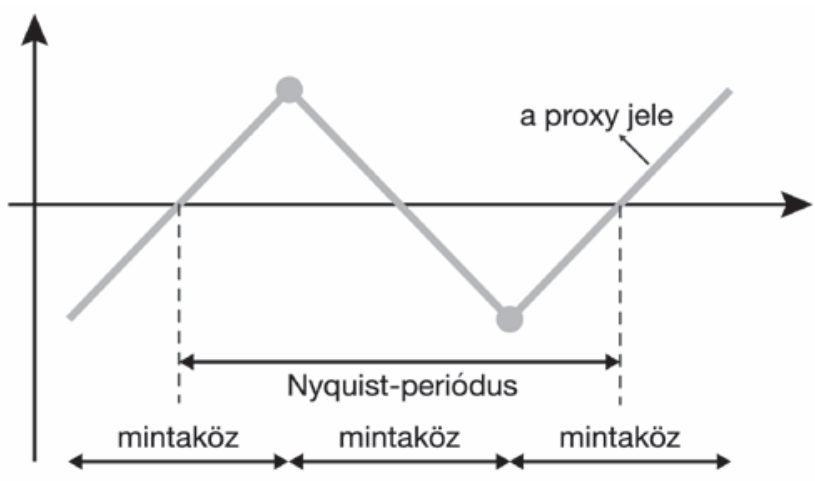

5. ábra. A Nyquist-frekvencia az idősorból kimutatható legmagasabb frekvencia. Az ehhez a frekvenciához tartozó, az idősorból kimutatható legkisebb periódus a Nyquist-periódus. Mivel egy ciklus kimutatásához hullámhosszonként legalább két mintapontra van szükség (szürke pontok), így a Nyquist-periódus hossza a mintaköz hosszának kétszerese

Figure 5. The Nyquist-frequency is the highest frequency that can be detected from a time-series. The period which belongs to this frequency is the smallest period that can be detected from a time-series, called the Nyquist period. Because a cycle requires at least two data points per wavelength (grey dots) to become detectable, the length of the Nyquist-period is twice the length of the sample interval dusonként csak két mintapontot rögzítünk, az a jel nem kívánt alul-mintavételezését (aliasing) okozhatja. Az alulmintavételezés eredményeként a nagyobb frekvenciájú ciklusok nem lesznek kimutathatóak a jelben. Ennek megelőzése érdekében tehát fontos, hogy a Nyquist-frekvencia által meghatározott mintaköznél súrúbben mintázzunk. Bár a kimutathatatlanná vált ciklusok utólag nem nyerhetôek ki a simított jelből, arra van mód, hogy a simítás kisebb frekvenciákra gyakorolt negatív hatását minimalizáljuk. Ilyen hatású természetes folyamat a bioturbáció a konszolidálatlan üledék átkeverése során, de ún. csatornamintázással (channel sampling) magunk is átlagolhatjuk az egyes proxyk értékeit adott szakaszonként, sôt egyes adatelemző programok is kínálnak erre lehetőséget (pl. anti-aliasing szúrő) (WEEDON 2003). A mintavételezés szempontjából nemcsak a legnagyobb, hanem a legkisebb kimutatni kívánt frekvencia is különös figyelmet érdemel. Egy ciklusnak a jelben legalább négyszer, de inkább hatszor ismétlődnie kell ahhoz, hogy megbízhatóan és pontosan ki lehessen azt mutatni (WEEDON 2003).

Az adatsor vizsgálatra való előkészítése a jel-zaj arány növelését szolgálja. Először a kiugró értékeket kell eltávolítani, ugyanis ezek az egységimpulzus hatásán keresztül erősen megnövelhetik a később előállított spektrumok zajosságát, bizonyos szakaszokon akár értelmezhetetlenné is tehetik azokat. A kiugró értékek eltávolítására ugyan vannak statisztikai módszerek, ám a ciklussztratigráfiában ez időnként mégis szubjektív. Fontos a nagyon zavaró vagy a mérési hibából adódóan téves értékek kiszúrése, azonban ha meggondolatlanul túl sok értéket távolítunk el a vizsgált idősorból, az egy idő után károsan befolyásolja az eredményt, mert a ciklusok egyre kevésbé válnak észlelhetővé, vagy el is tûnhetnek. Érdemes először a kiugró, hibásnak vélt értékekkel együtt is elvégezni a vizsgálatot és megfigyelni, melyek vannak a legrosszabb hatással az eredményre. A kiugró értékek eltávolítását az interpoláció követi. A lineáris interpoláció a mintapontokat egyenes vonalakkal köti össze, és az így létrejött görbét egyenközúleg újramintázza úgy, hogy az új mintapontok közötti mintaköz az általunk meghatározott érték lesz. Természetesen más típusú interpoláció is használható. Az új mintaköz ideális esetben nem térhet el az eredeti mintaköztôl, nem egységes eredeti mintaközök esetén azok átlagát célszerú új mintaközként megadni. Az interpolációra főleg azért van szükség, mert a vizsgálat későbbi lépései során a legtöbb módszer egyenközú mintázást követel meg (WEEDON 2003, Li et al. 2019a).

A zaj csökkentését szolgálja a trendeltávolítás (detrending) eljárása is. A trendeltávolítás célja egy nagyjából 0 körül oszcilláló idősor létrehozása. Ez nem csak a fenti okból, de a jelben szereplő periodicitások amplitúdója szempontjából is fontos. Ehhez szintén több matematikai módszer áll rendelkezésre az adatelemző programokban. Egyszerú (pl. folyamatos növekvő vagy csökkenő) trendek esetén kielégítő lehet a lineáris regresszió számítása és ennek kivonása az idősorból, ám gyakran ennél bonyolultabb eljárások szükségesek. Az összetett, pl. hol növekvő, hol csökkenő trendek eltávolításához többszörös lineáris regresszió, polinomiális 
regresszió, illetve Lowess- és Loess-simítás, valamint ezek robusztus, a kiugró értékek hatására kevésbé érzékeny változatai is használhatóak. Körültekintően kell azonban eljárni annak elkerülése érdekében, hogy a trendeltávolítás során óvatlanul a nagyobb periódusidôvel rendelkezô periodicitásokat is eltávolítsuk az idősorból (WEEDON 2003, Li et al. 2019a).

A fenti három adatelőkészítési módszer kötelezően végrehajtandó a ciklussztratigráfiai vizsgálatok során. Ezek mellett igen gyakran alkalmazott eljárás a log-transzformáció, amelyet azonban nem szükséges minden esetben elvégezni. A trendeltávolítás során az adatsor átlaga stabilizálódik, stacionáriussá válik, azonban bizonyos idősorok megkövetelhetik a variancia stabilizálását is. Erre például akkor lehet szükség, ha a jel hosszú távú amplitúdócsökkenést vagy növekedést mutat. Ezt a problémát a log-transzformáció oldja fel, melynek során a mintapontok értékeit azok tízes alapú logaritmusával helyettesítjük. A log-transzformációt, amennyiben szükség van rá, legelsô lépésként kell elvégezni az idôsor előkészítése során, esetleg követheti a kiugró értékek eltávolítását, de fontos, hogy a transzformáció után újra ellenőrizzük, nem keletkeztek-e újabb kiugró értékek (WEEDON 2003, Li et al. 2019a).

\section{Spektrálanalízis}

Az egyes ciklusok felismeréséhez az idősort fel kell bontani különböző hullámokra, ezt végzi el a Fourier-transzformáció. A Fourier-transzformáció azon az elven alapul, hogy minden idősor előállítható megfelelő amplitúdójú és hullámhosszú szinusz és koszinusz hullámok összegéből. A matematikai múvelet eredménye megmutatja, hogy az adott frekvencián milyen teljesítményú szinuszoid hullámok vannak jelen a vizsgált idősorban. Emellett a Fourier-sorfejtés során az időtől függô változókat frekvenciától függő változókba transzformálja. Egy adott frekvenciához mindig tartozik egy szinusz és egy koszinusz hullám, melyek átlagos amplitúdóértékeinek négyzetösszegét nevezzük az adott frekvencia teljesítményének (BLOOMFIELD 2000, WEEDON 2003).

A diszkrét Fourier-transzformáció, vagy röviden DFT (Discrete Fourier Transform) a Fourier-transzformáció egy olyan fajtája, mely egyenközú, folytonos jelú idősorokra ideális (COOLEY \& TUKEY 1965). A DFT azonban igen nagy számításigényú, így ennek a sokkal gyorsabb és hatékonyabb változata, az ún. gyors Fourier-transzformáció, vagy FFT (Fast Fourier Transform) jóval elterjedtebbé vált. Mivel a legtöbb ciklussztratigráfiai bemenô adatsor egyenközú és folytonos jelú, ezért a vizsgálatokhoz általában ezeken az eljárásokon alapuló módszereket alkalmaznak (WEEDON 2003, Li et al. 2019a).

Az FFT alkalmazásához az adatsornak kettő egész számú hatványával megegyező darabszámú (pl. 256, 512, 1024 stb.) pontja kell legyen. Ha szükséges, az idősor mindkét vége kipótolható megfelelő számú 0 értékú mintaponttal), ezt nevezzük zero-padding-nek. A zero-padding azért is hasznos eljárás, mert a teljesítményspektrum felbontása a mintaszámtól függ, így a mintaszám virtuális megnövelésével a teljesítményspektrum felbontása is javítható (WEEDON 2003, Li et al. 2019a).
A Fourier-transzformáció eredményének grafikus ábrázolása a teljesítményspektrum (power spectrum) (6. ábra), ami a teljesítmény eloszlását a frekvencia függvényében mutatja. Az x tengelyen a frekvencia értékei 0-tól a Nyquistfrekvenciáig terjednek. Az eredeti idősor a teljesítményspektrumon ábrázolt frekvenciájú és teljesítményú hullámokra bontható fel. Ekképpen minél nagyobb egy adott frekvenciához tartozó teljesítmény, az azzal a frekvenciával bíró ciklus annál inkább vesz részt az eredeti jel alakjának kialakításában. Amelyik frekvenciánál a teljesítményspektrumon nagy teljesítményértékú, kiemelkedő csúcs látható, az a frekvencia a jelben rejlô fontos periodicitást jelent (WEEDON 2003, Li et al. 2019a).

A fenti módon létrehozott teljesítményspektrumoknak azonban van egy lényeges hibája, a spektrális szivárgás

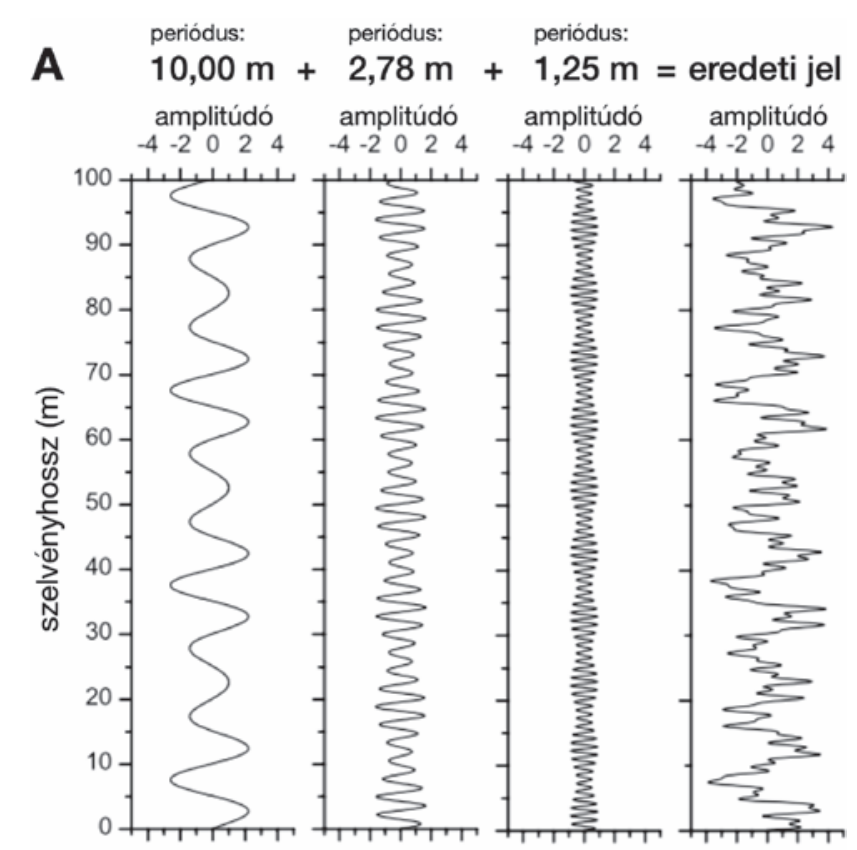

B

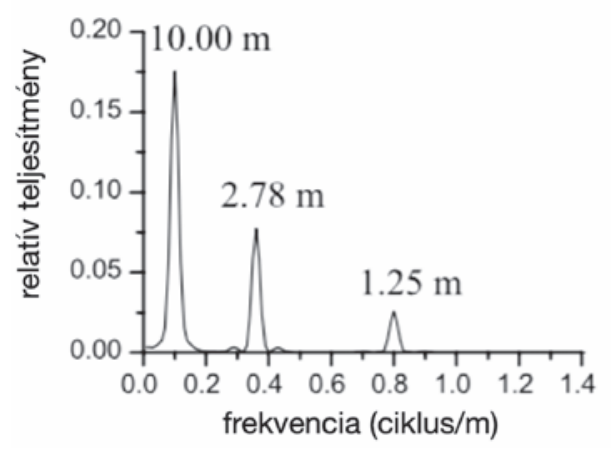

6. ábra. A) A Fourier-transzformáció egy idősor jelét szinuszoid görbékre bontja szét úgy, hogy ezek összege kiadja az eredeti jelet. B) A Fouriertranszformáció eredményének grafikus ábrázolása a teljesítményspektrum. (WEEDON 2003 alapján)

Figure 6. A) The Fourier-transform is a mathematical process to break down a timeseries signal into sinusoid waves, so the sum of these waves is the original signal. $B$ ) The graphic interpretation of the Fourier-transform is the power spectrum. (Based on WEEDON 2003) 
(spectral leakage) jelensége. A teljesítményspektrumok csúcsairól bizonyos mennyiségú teljesítmény elszivárog és más frekvenciáknál jelenik meg. A teljesítményvesztés elsôsorban a kis frekvenciákat érinti, míg a nem valódi teljesítmény általában a nagy frekvenciáknál jelenik meg. A szivárgás arra vezethetô vissza, hogy a vizsgált idősorok véges kiterjedésúek, és hirtelen végződnek el. Ezt a problémát az ablakolás (tapering) módszerével lehet kiküszöbölni. Ennek során az eredeti jelet különböző súlyfüggvényekkel szorozzuk be, majd az így létrejött új jelen végezzük el a Fourier-transzformációt. A leggyakrabban használt súlyfüggvény a jelet középen 1-gyel, a két végén pedig 0-val szorozza meg, így az elvégződés folyamatossá válik. Az eljárás hátulütője, hogy adatvesztéssel és így simítással, valamint a felbontás csökkenésével jár együtt (WEEDON 2003, Li et al. 2019a).

A legjobb kompromisszumos megoldást a szivárgási hiba minimalizálása mellett az eredeti jel és felbontás lehető legjobb megórzésére az ún. multitaper módszer, vagy rövidítve MTM (Multi-Taper Method) adja. Az eljárás során az eredeti jelet három különbözô ortogonális (azaz egymásra meróleges) függvénnyel szorozzuk be, majd mindegyiken különkülön elvégezzük a diszkrét Fourier-transzformációt, illetve gyakrabban annak gyors Fourier-transzformáció változatát. Az így létrehozott három teljesítményspektrum értékeinek átlagaiból áll elố a $2 \pi$-MTM teljesítményspektrum, vagyis a multitaper módszer teljesítményspektruma. A $\pi$ a használt súlyfüggvények számát jelenti. A súlyfüggvények számának kétszerese, vagyis $2 \pi$ a szabadságfok. Minél nagyobb ennek értéke, vagyis minél több súlyfüggvényt használunk, a $2 \pi$ MTM teljesítményspektrum felbontása annál jobban leromlik (ThOMSON 1982, 1990; PERCIVAL \& WALDEN 1993; LeES \& PARK 1995; MANN \& LEES 1996; WEEDON 2003).

A teljesítményspektrumok előállítására több további módszer is létezik, mint például a Welch-módszer (WELCH 1967) vagy a Blackman-Tukey módszer (BLACKMAN \& TUKEY 1958), ám ezek ismertetésétől itt két okból eltekintünk. Egyrészt a ciklussztratigráfiában a leginkább elismert és széles körben használt eljárás a multitaper módszer, másrészt a többi módszer is hasonló elvek alapján és hasonló módon múködik, viszont valamilyen más problémára specializálva fejlesztették ki azokat, a multitaper módszer elterjedése előtt (PERCIVAL \& WALDEN 1993).

Ahhoz, hogy meg tudjuk ítélni, a teljesítményspektrum mely csúcsai emelkednek ki a háttérzajból, vagyis mely csúcsok szignifikánsak és tartozhatnak tényleges, szabályos periodicitáshoz, fontos a háttérzaj megállapítása. A ciklussztratigráfia során a zaj két tényezőből tevődik össze. Az ún. fehér zaj (white noise) a mérési hibából adódik. Minden mérési pont nagyjából ugyanakkora hibával terhelt, így a fehér zajból adódó teljesítmény minden frekvencián nagyjából azonos teljesítménnyel jelenik meg. A nevét onnan kapta, hogy a fehér fényben minden frekvencia azonos teljesítménnyel bír. Tulajdonságából adódóan ez a zaj kevésbé zavaró, hiszen hiába növeli meg a zajhoz tartozó csúcsok teljesítményét és így magasságát, arányosan ugyanannyival megnöveli a szignifikáns, kiugró csúcsok magasságát is, így azok könnyen elkülöníthetőek maradnak (WEEDON 2003).
Nagyobb problémát okoz az ún. vörös zaj (red noise), mely nagyságrendekkel nagyobb mértékben van jelen a ciklussztratigráfiai idôsorokban. Ezt a zajt a Föld pályaelemei által hajtott éghajlati tényezők okozzák. A légkör vagy az óceánok természetes módon, tehetetlenségükből adódóan késve reagálnak a pályaelemek változására. Ennek következtében a vizsgált idôsor adott értéke nem független az előtte lévőktől. Az elsőrendû autoregressziós modellben egy adott változó függ az azt megelőzô változótól, így idősorok esetében alkalmas a vörös zaj modellezésére. Tulajdonságaiból fakadóan a vörös zaj sokkal erősebb a kis frekvenciák tartományában, és ereje a nagyobb frekvenciák felé lényegesen csökken. Nevét is onnan kapta, hogy a vörös fényben a kis frekvenciák az uralkodóak (MANN \& LEES 1996, WeEdon 2003, Meyers 2012, Li et al. 2019a).

A ciklussztratigráfiában hagyományosan nem távolítjuk el a háttérzajt, bár vannak rá módszerek (pl. előfehérítés, pre-whitening). Ehelyett a zaj a teljesítményspektrumokon megbízhatósági szintek segítségével kerül kifejezésre. Az ez alatt a szint alatt maradó csúcsok adott valószínúséggel a hattérzajhoz tartoznak, míg az ezt átlépő csúcsok valószínúleg szabályos periodicitásokat (pl. Milanković-ciklusokat) képviselnek. Konvencionálisan a teljesítményspektrumokon a 90\%-os, 95\%-os és 99\%-os megbízhatósági szintek kerülnek ábrázolásra (MANN \& LEES 1996, WEEDON 2003, Meyers 2012, Li et al. 2019a).

Bár a megbízhatósági szintek általában jól használhatóak, a természetben gyakran előfordul eltérés az ideális esettôl. A periodicitások teljesítményét számos tényező befolyásolhatja, pl. a zaj, a spektrális szivárgás vagy a nem megfelelő proxy, de adott földtörténeti korban és környezetben természetesen is megőrződhet gyenge jellel egy ciklus. Előfordulhat, hogy egy létező periodicitás nem lépi át a megbízhatósági szinteket, illetve egy háttérzajból származó csúcs akár több megbízhatósági szint fölé is emelkedik. Ilyen esetekben segíthet az F-teszt. Ez az eljárás konstans fázissal rendelkező, kvázi szabályos ciklicitásokat keres és megmutatja, hogy a teljesítményspektrum csúcsai közül melyek rendelkeznek ilyen tulajdonságokkal. Azonban az F-teszt eredménye sem alkalmas a kérdés egyértelmú eldöntésére, és így a csúcsok értelmezésében a vizsgálatot végző személy mérlegelése is szerepet kap. Gyakori módszer ezenkívül, hogy az idősort két vagy több, át nem fedô részre vágják szét és mindegyikre elkészítik a teljesítményspektrumot. Amennyiben a szignifikánsnak vélt csúcs mindegyik teljesítményspektrumon közel azonos frekvencián megjelenik, figyelembe véve, hogy helyzete a felbontás és a rétegsor menti üledéklerakódási sebesség változása miatt eltolódhat, úgy a csúcs valós ciklust reprezentál. Azonban, ha az adott csúcs csak egy teljesítményspektrumon jelenik meg, úgy megnô annak a valószínúsége, hogy csak a háttérzajhoz tartozó csúcsról van szó. Hasonló megfontolásból, a megbízhatóság növelése érdekében érdemes egy-egy rétegsor vizsgálatát több klímaproxyra is kiterjeszteni és ezek eredményeinek összehasonlítása az előbbiekkel megegyező módon erôsítheti vagy gyengítheti a feltételezéseket (THOMSON 1982, 1990; LEES \& PARK 1995; WEEDON 2003). 
Míg a teljesítményspektrum átlagolt képet mutat, addig a teljesítményspektrum időbeli változását a spektrogram (evolutionary spectra) (7. ábra) segítségével tudjuk megfigyelni. A spektrogram függőleges tengelyén legtöbbször a rétegtani szint, ritkábban a relatív idő szerepel, míg a vízszintes tengelye megegyezik az ugyanabból az adatsorból készített teljesítményspektruméval, vagyis frekvencia értékeket mutat. A színek a teljesítményspektrum függőleges tengelyének, vagyis a teljesítménynek felelnek meg (WEEDON 2003, HiNNOV \& HiLGEN 2012, MARTINEZ et al. 2015, LI et al. 2019a). A spektrogram sok egymás utáni, az idősor más és más szakaszain, azaz egymást követô ablakokban elvégzett FFT-vel hozható létre. Az ablakok szélessége azt jelöli, hogy milyen hosszú szakaszt vizsgálunk az idősorból egy-egy ablakban, az ablakok lépésköze pedig azt határozza meg, hogy az egymást követő ablakok középpontjai között mekkora a távolság. Az egyes ablakok szélessége nagyobb a lépésköznél, biztosítva az ablakok átfedését. A lépésköz és ablakszélesség méretét a vizsgálatot végző kutatónak kell megállapítania, ugyanis az minden egyes idősor és vizsgálat esetében eltérô, az adott feladatra jellemzően testre szabható. Széles ablakok esetén nagy felbontású képet kapunk az idősor nagy részéről, viszont a spektrogram elkészítésének eredeti célja, hogy a jel kisebb szakaszairól kapjunk információt. Ehhez szúk ablakok szükségesek, ami viszont a felbontás romlásával jár. Túl széles ablakok esetén a nagy frekvenciákhoz tartozó periodicitások válhatnak láthatatlanná, míg túl keskeny ablakszélesség esetén a kis frekvenciák tûnhetnek el a spektrogramról. A lépésköz mértékét a mai ciklussztratigráfiai programok automatikusan és jórészt helyesen (általában a mintavételi távolsággal egyenlően) határozzák meg. Az ablakszélesség választásánál egy tapasztalaton alapuló ajánlást érdemes követni, a teljesítményspektrum szignifikáns csúcsai közül a legkisebb frekvenciával rendelkezőt figyelembe véve. Ennek a frekvenciaértéknek a reciproka az adott ciklus periódusa, ablakszélességnek pedig ennek a periódusnak a másfélszeresét érdemes beállítani (WEEDON 2003, Li et al. 2019a).

A spektrogramon az egyes frekvenciához tartozó sávok többnyire nem teljesen egyenesek és függólegesek. Ez egyrészt a mérési hibának, kiugró értékeknek, azaz a zajnak, másrészt az üledéklerakódási sebesség változásainak köszönhetô. Amennyiben a sáv rétegtani értelemben felfelé haladva a kisebb frekvenciák irányába mozdul el, az az üledéklerakódási sebesség növekedését jelenti a vonatkozó szakaszon, megfordítva pedig a magasabb frekvenciák felé mozdulása az üledéklerakódási sebesség csökkenésére utal (7. ábra) (WEEDON 2003, MARTINEZ et al. 2015).

A teljesítményspektrumon szignifikánsnak adódó periodicitások a spektrogramon ellenőrizhetőek. Amennyiben a periodicitás valós ciklushoz tartozik, úgy az idősor teljes hosszán vagy legalábbis hosszú szakaszain keresztül meg

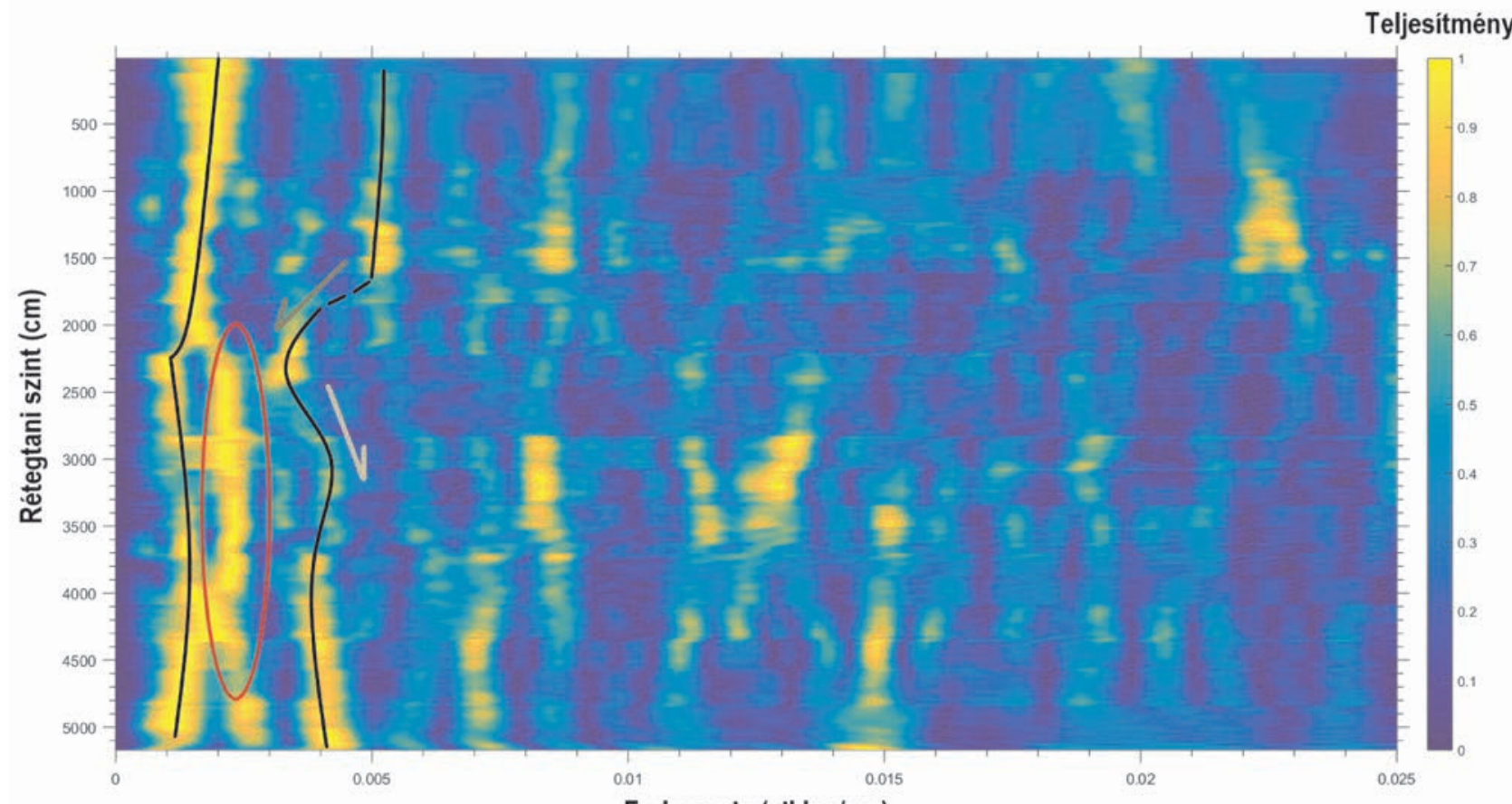

7. ábra. A spektrogram a jel ablakszélesség által meghatározott szakaszaira készült teljesítményspektrumokból áll össze. A spektrogramon a két szignifikáns periodicitás lefutását feketével jelöltük. Jól látható, hogy a két sáv nem teljesen függőleges, lefutása hajladozó. A vörössel bekarikázott interferenciajelenség esetében a két sáv túl közel került egymáshoz, ezért közöttük megjelent egy új, hamis sáv. A sötétbarna nyíl az üledéklerakódási sebesség növekedésének, míg a világosbarna nyíl az üledéklerakódási sebesség csökkenésének szakaszait jelöli. (Az ábra az Acycle program [Li et al. 2019a] segítségével készült)

Figure 7. The spectrogram consists of power spectra made for sections of the signal defined by the window width. In this spectrogram, the two significant periodicities are marked with black lines. Clearly, the two bands are not strictly straight and vertical but bending. Circled in red, an interference pattern occurs where the two bands closely approach each other and a new, false band appears between them. The dark brown arrow indicates an increase, whereas the light brown arrow indicates a decrease in sedimentary rate. (The figure was produced using the Acycle program of LI et al. 2019a) 
kell jelennie a spektrogramon is. Ennek értelmezése azonban tapasztalatot igényel, mivel a spektrogram egyes szakaszain a keresett jel eltúnhet a zaj vagy egyéb matematikai problémák miatt, mint pl. túl sok interpolációval adatpótolt mintapont jelenléte egy szakaszon belül. Továbbá, ha egy gyenge periodicitás egy erősebbhez túl közel kerül, pl. az üledéklerakódási sebesség változása miatt, interferencia léphet fel. Az interferencia abban nyilvánul meg, hogy erôsségével fordított arányban mind a két sáv elmozdul egymás irányába az adott szakaszon, vagy akár a két sáv közé eső frekvencián egy hamis sáv jelenhet meg. A hamis sáv erősségének függvényében a két eredeti, valós sáv teljesítményt veszít, vagyis gyengül (7. ábra) (WEEDON 2003, MARTINEZ et al. 2015, MARTINEZ et al. 2016).

A wavelet-analízis ugyan nem tartozik szigorúan a spektrálanalízis módszertanához, azonban alkalmazása hasznos információkkal szolgálhat. A már bemutatott módokhoz hasonlóan hoz létre teljesítményspektrumot és spektrogramot (8. ábra), azonban nem szinusz és koszinusz hullámok, hanem ún. wavelet-hullámok felhasználásával. Ezek sajátságaiból adódóan a frekvenciafelbontás a kis frekvenciák esetében lényegesen jobb lesz, a rétegtani helyzet azonban a spektrogramon gyakorlatilag azonosíthatatlanná válik. Fontos előnye a módszernek, hogy segítségével a mintaköznél nagyobb hiátusok kimutathatóvá válnak, ugyanis a spektrogramon a rétegtani hiányt tartalmazó szakaszon eltûnik minden jel, minek következtében a spektrogramon keresztben egy fehér sáv jelenik meg (8. ábra) (WEEDON 2003, HAMMER \& HARPER 2006 2006, Li et al. 2019a).

\section{A Milanković-ciklusok azonosítása és kormodell készítése}

A vizsgálat során felismert periodicitások Milankovićciklusoknak való megfeleltetésére több módszer létezik, melyek közül a legegyszerúbb az ún. aránymódszer. Mivel a periodicitásokhoz tartozó frekvenciák reciproka megadja a periódusukat, ezek arányát összehasonlíthatjuk a Milanko- vić-ciklusok periódusidőinek arányaival. Kitüntetett jelentőségú a 20:5:2:1 arány keresése, ahol az 1 a precesszió periódusidejét (kb. 20 ezer év) jelöli. Ennek kétszerese (kb. 40 ezer év) a tengelyferdeség, ötszöröse (kb. 100 ezer év) a rövid excentricitás, húszszorosa (kb. 400 ezer év) pedig a hosszú excentricitás periódusidejének felel meg. A keresett arányokat a vizsgált rétegsor korának megfelelően kismértékben szükséges lehet módosítani. Számolni kell azzal is, hogy az üledéklerakódási sebesség változásának függvényében a periodicitások átvándorolhatnak más frekvenciára, így amenynyiben a spektrogram lehetőséget nyújt rá, vizsgáljuk meg, hogy a periodicitások végig megtartják-e ezt az arányt (WEEDON 2003, MEYERS \& SAGEMAN 2007, Li et al. 2019a).

A ciklussztratigráfia fejlődése során felmerült egy kifinomultabb kvantitatív azonosítási mód igénye, amit először az ASM (Average Spectral Misfit) módszerrel valósítottak meg (Meyers \& Sageman 2007, Meyers 2014). Ennek újabb alternatívája az Acycle programban implementált korrelációs együttható, vagy röviden $\mathrm{COCO}$ (COrrelation $\mathrm{CO}$ efficient) funkció, mely az ASM-módszer továbbfejlesztésén alapul (Li et al. 2019a). A COCO kiszámítja a korrelációs együttható értékét a felhasználó teljesítményspektruma (a rétegtani szint függvényében ábrázolva) és egy csillagászati modell teljesítményspektruma (az idő függvényében ábrázolva) között, több üledéklerakódási sebesség mellett is. Ezzel egy időben a felhasználó idősorát térfüggőből időfüggővé transzformálja. Eredményeképpen a legmagasabb korrelációs együtthatóval rendelkezô üledéklerakódási sebesség valószínúsíthetô a rétegsorra. Eközben a program Monte Carlo-szimulációt is végez, mely során az adott üledéklerakódási sebesség mellett több, random frekvenciájú és amplitúdójú hullámokból álló teljesítményspektrum csillagászati modellel való korrelációs együtthatóját is vizsgálja, feltételezve, hogy a periodicitások nem a Milankovićciklusokhoz tartoznak. Ennek a feltételezésnek a megbízhatósági szintje így megmutatja, hogy az adott korrelációs együtthatók milyen valószínúséggel fordulnak elő véletlenül. Amennyiben például a feltételezés megbízhatósági
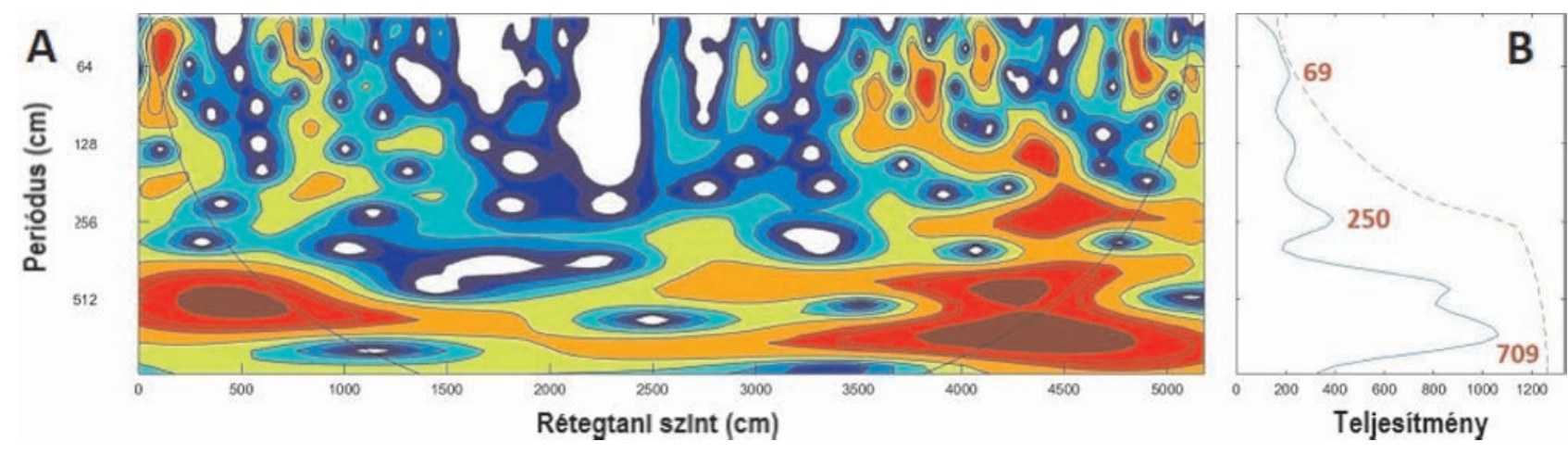

8. ábra. A wavelet-analizis eredményeképp létrejött wavelet spektrogram (A) és wavelet teljesítményspektrum (B). A kb. $2300 \mathrm{~cm}-n e ́ l$ megfigyelhető fehér sáv ebben az esetben egy megmintázatlan szakasz miatt jött létre. Amennyiben a rétegsorban lenne hiátus, egy ehhez hasonló, ám az egész spektrumot keresztülvágó fehér sáv jelenne meg. (Az ábra az Acycle program [Li et al. 2019aG segítségével készült.)

Figure 8. Results of wavelet analysis: wavelet spectrogram (A) and wavelet power spectrum (B). The white band hanging from above approx. at $2300 \mathrm{~cm}$ was created in this case due to an unsampled section. If there were a sedimentary gap in the succession, a similar white band would appear, but cut across the entire spectrum. (The figure was produced using the Acycle program of Li et al. 2019a) 
szintje $1 \%$, úgy adott üledéklerakódási sebesség mellett a vizsgált idősor teljesítményspektruma és a csillagászati modell teljesítményspektruma közötti korrelációs együttható értéke a tesztelt esetek korrelációs együtthatóinak 99\%-át meghaladja. Ez alapján feltételezhetjük a teljesítményspektrum és a csillagászati modell jó egyezését, vagyis a Milanković-ciklusok jelenlétét a vizsgált jelben (HINNOv \& HiLGEN 2012, LI et al. 2019a). Amennyiben több különböző üledéklerakódási sebességnél is magas a korrelációs együttható (a tapasztalatok alapján ciklussztratigráfiában már a korrelációs együttható kb. 0,4 értéke is magasnak számít az el nem távolított zaj miatt), vagy eleve sejthetô az üledéklerakódási sebesség megváltozása a vizsgált rétegsor mentén, úgy ezt is lehetôségünk van tesztelni a COCO eCOCO funkcióval, amelynek implementációja a spektrogramhoz hasonlóan ablakolással történik (Li et al. 2019a).

A COCO vagy az ASM használatakor figyelembe kell venni, hogy ezek a módszerek a csillagászati kalibráción alapulnak, amelynek használata 50 millió évnél idősebb rétegsorokon téves megállapításokhoz vezethet. 50 millió évnél fiatalabb rétegsorok esetén ezután nincs szükség további lépések végrehajtására, a Milanković-ciklusok azonosítása után sor kerülhet a csillagászati kalibrációra. Ennek ellenére az ilyen szelvények esetében is ajánlatos lehet inkább lebegô korskálát létrehozni a kevesebb és kisebb hibalehetőség miatt, különösen a pleisztocénnál idősebb képződmények esetében (WEEDON 2003, HinNOV 2013, Li et al. 2019a)

50 millió évnél idősebb rétegsor esetén a Milankovićciklusok azonosítása után a kormodell elkészítéséhez ki kell választani azt a ciklust, amely a legjobban őrződött meg a jelben, vagyis amelyik a rétegsor lehetô legnagyobb hosz-szában megfelelő erôsséggel van jelen, majd ezt ki kell szûrni az idôsorból. Bár a szűrôzéshez korábban alul és felül áteresztő szűrőket (low-pass és high-pass filter) is alkalmaztak, mára általánossá vált az ún. sáváteresztô szûrôk (band-pass filter) használata, melyek közül leggyakrabban a Gauss-, a Taner- és a Taner-Hilbert-szúröket választják (WEEDON 2003, ZEEDEN et al. 2018, Li et al. 2019a). Az alul áteresztő szúrôk az alacsony frekvenciákat engedik át, tartják meg, és a magasakat távolítják el, míg a felül áteresztô szúrôknél ez pont fordítva van. A sáváteresztô szúrôk segítségével ezzel szemben a teljesítményspektrumról pontosan kiválasztható az a frekvenciatartomány, amelyhez a fenti szempontok szerint kiválasztott ciklus társul. A sáváteresztő szưrô ezek után kiszúri a jelből az ehhez a frekvenciához tartozó szinuszoid jelet. Ennek amplitúdója a korábban ismertetett okok miatt nem állandó, sốt az üledéklerakódási sebesség miatt frekvenciája is változni fog a korábban beállított frekvenciatartományon belül. A kiszûrt jel csúcsaihoz ezek után a ciklushoz tartozó Milanković-ciklus periódusidejének ismeretében rendelhetünk relatív időt. Például, ha a kiválasztott ciklus a 405 ezer éves periódusidejú hosszú excentricitás, akkor minden következő csúcs a kiszûrt jelen 405 ezer év elteltét jelenti az előzó csúcshoz képest. Ezen az úton hozható létre a lebegô korskála (WEedon 2003, ZeEDEN et al. 2015, Li et al. 2019a).

\section{Szoftverkörnyezet}

Jelenleg több szoftver segítségével is végezhetôk ciklussztratigráfiai vizsgálatok. Az Acycle program rendkívül felhasználóbarát és egyszerúen kezelhetô (Li et al. 2019a). Ezeken felül az Acycle ingyenes, és Mac, illetve Windows operációs rendszerben is futtatható MATLAB, vagy annak szintén ingyenesen elérhető MATLAB Runtime környezetben. Ugyancsak nyílt hozzáférésú alternatívája az R környezetben fejlesztett astrochron-csomag (MEYERS 2014). Mindkét program részletesen dokumentált, így könnyen tanulható.

\section{A ciklussztratigráfia hazai alkalmazásai}

Magyarországon nemzetközi összehasonlításban kevés ciklussztratigráfiai témájú tanulmány született, és bár ezek mindegyike a maga idejében előremutató volt, közülük mindössze kettő (BAJNAI et al. 2017, MüLLER et al. 2017) használta az itt bemutatott modern módszertant. Az alábbiakban rövid ismertetést adva időrendben tekintjük át a tudományterület hazai eredményeit.

BACSÁK GYÖRGY elévülhetetlen érdemeket szerzett a Milanković-ciklusok elméletének korai kidolgozásában, fejlesztésében és magyarországi bevezetésében (MAJOR 2006). Ebben közrejátszott az is, hogy évtizedeken át szakmai levelezésben állt Milankovićcsal. BACSÁK (1954) a pliocén és pleisztocén idején bekövetkezett glaciálisok és interglaciálisok összefüggését vizsgálta a pályaelemek változásából következô eltérô besugárzással, meglátásait részletes égi mechanikai számításokkal is alátámasztva.

SzEDERKÉNYI (1963) a Szilágy környékén mélyített Szilágy-II és Martonfa-I fúrásban vizsgált mikrorétegzett diatomit és márga váltakozásából álló szarmata rétegsorokat. Feltételezte, hogy egy diatomit-márga mikrorétegpár egy évet képvisel, a márga nyáron, míg a diatomit télen rakódott le. Ezek alapján számításai szerint a két rétegsor valamivel kevesebb mint 700 ezer év alatt rakódott le. Megvizsgálta továbbá azt is, hogy egy-egy mikrorétegpár esetében menynyire éles az elkülönülés, és ennek segítségével hosszabb távú ciklusokat is ki tudott mutatni, melyek szerinte közel azonos periódusidővel rendelkeznek, mint a BACSÁK (1954) által bemutatottak.

SCHWARZACHER \& HAAS (1986) a Dachsteini Mészkó Formációt harántoló egyes dunántúli mélyfúrások (Po-89, Ut-8 és T-5) és ausztriai szelvények rétegsoraiban előforduló Lofer-ciklusokat vizsgálta ciklussztratigráfiai szempontból, a vastagságarányok tekintetében. A vizsgálat során abban az időben korszerú matematikai módszereket is használtak, melyek segítségével több ciklust sikerült kimutatniuk. A legalacsonyabb rendú ciklust a precessziós ciklusnak feleltették meg, így a periódusok aránya alapján a többi, magasabb rendú ciklus periódusideje közel esett a tengelyferdeség és a rövid excentricitás ciklusainak periódusidejeihez.

HAAs et al. (1994) Sümegen a felsố jura - alsó kréta Mogyorósdombi Mészkő Formáció feltárását vizsgálták. Vékonycsiszolatok segítségével kimutatták a képződmény- 
ben a calpionellák és a radiolariák mennyiségének egymással ellentétes, antifázisú, de ciklikus változását. A ciklussztratigráfiai vizsgálathoz az akkoriban rendelkezésre álló egyik legmodernebb, a ma használatos módszertan elődjének tekinthető módszertant alkalmazták, melynek segítségével három szignifikáns csúcsot sikerült kimutatniuk. Ezeket, tekintve hogy a vizsgált rétegsor nagyjából a berriasi emeletnek feleltethetô meg, és ennek hosszára akkoriban mintegy 6 millió évet valószínúsítettek, sorban az 1 millió éves, 410-570 ezer éves és a 120-190 ezer éves ciklusoknak feleltették meg, melyek közül az utóbbi kettô periódusideje közel esik az excentricitási ciklusokhoz. A ciklusok hosszának kiszámítása úgy történt, hogy a 6 millió évet képviselő, 144 m vastag rétegsort arányosan elosztották a ciklussztratigráfiai vizsgálat során kapott periódusokkal.

A magyarországi alsó kréta jellegzetes, a franciaországi Voconti-árok sokat tanulmányozott márga-mészkő rétegeihez hasonló üledékeit, a Berseki Márga Formációt két ciklussztratigráfiai tanulmány is vizsgálta. FOGARASI (1995) a Berseki Márga Formáció legfelsố és az azt fedô Lábatlani Homokkő Formáció alsó szakaszának rétegein becsülte meg az üledékképződés sebességét a feltárt rétegsor vastagságára és annak feltételezett képződési időtartamára alapozva. A ciklussztratigráfiai vizsgálatot később BAJNAI et al. (2017) terjesztette ki az itt bemutatott korszerú módszertan felhasználásával, a Berseki Márga mélyebb helyzetú szürke márga rétegcsoportjára fókuszálva. Mivel a szürke márgában az egyes rétegek közötti litológiai kontraszt kicsi, és így a rétegvastagságok mérése nehezen lehetséges, BAJNAI et al. (2017) négy geokémiai proxy jelét vizsgálta egyenközú mintavételt követôen. A $\delta^{13} \mathrm{C}$, a mágneses szuszceptibilitás és a természetes gammasugárzás jelében kimutatta a rövid excentricitási, a tengelyferdeségi, illetve a precessziós ciklusokat, amelyek segítségével meghatározta, hogy a vizsgált rétegsor 1,49 millió év alatt rakódott le. BAJNAI et al. (2017) további fontos megállapítása, hogy a Berseki Márgában mért $\delta^{13} \mathrm{C}$-értékek a Voconti-árokban vizsgált rétegsorokkal való összehasonlítás alapján a Weissert-esemény pozitív szénizotóp-anomáliájának platójával korrelálhatók, így általuk az anomália időtartama meghatározható.

BALOG et al. (1997) bakonyi és gerecsei mélyfúrások felső triász rétegsorát (Fődolomit és Dachsteini Mészkő Formációk) tanulmányozták, és mutattak ki bennük méterskálájú ciklusokat (melyek a peritidális karbonátokra jellemző Lofer-ciklusok), valamint ezek nagyobb kötegekbe rendeződését. Az elemi, méterskálájú ciklusokat ezek után a precesszióhoz kapcsolták, feltételezve, hogy a rhaeti hossza 2 millió év (ma is vitatott, OGG (2012) 4-9 millió évnek becsüli), ugyanis az egyik vizsgált rétegsorban (tatai Kálvária-domb, T-5 sz. fúrás) 100 ilyen ciklusból áll a rhaeti emelet, ami kb. 20 ezer éves periódusidőt jelentene. Megfigyelték továbbá, hogy ezek az elemi ciklusok periódusidő tekintetében a rövid és hosszú excentricitási Milanković-ciklusoknak megfelelő arányokban rendeződnek nagyobb kötegekbe vastagság szerint. Elvégeztek egy akkoriban modernnek számító spektrálanalízist is, mely tovább erôsítette eredményeiket, és kimutatott egy, az elemi cik- lusnál kb. 2,5-szer nagyobb ciklust is, mely a tengelyferdeségi ciklust jelentheti.

JUHÁSZ et al. (1997) és JuHÁSZ et al. (1999) pannóniai rétegsorokon (Kask-2, Tp-1, Szh-II, Ib-1 fúrások) végeztek ciklussztratigráfiai témájú vizsgálatokat. A fúrásokban a homok-, aleurit-, agyag- és szén-rétegek vastagságát használták kiindulási adatként, majd ezekből az adatsorokból matematikai módszerekkel különböző frekvenciával bíró ciklikus trendeket simítottak ki. Az egyes trendekben észlelhető ciklusokat magnetosztratigráfiai korreláció során látták el időadattal. Az így kapott ciklusok periódusideje: 19 ezer év (precesszió), 71, illetve 50 ezer év (tengelyferdeség), 370, illetve 400 ezer év (hosszú excentricitás). Ezek mellett bizonytalanul észleltek még egy egymillió évnél hosszabb periódusidővel rendelkező ciklust is.

REZEssy (1998) az alsó jura Pisznicei Mészkő Formáció három rétegsorát vizsgálta a tatai Kálvária-dombon és a Gerecsében (Tölgyháti-kőfejtő, tardosi Bánya-hegy). A képződmény rétegeinek ciklikus, vastagság szerinti kötegekbe rendeződését főként litológiai bélyegek (pl. a rétegek és kötegek közti agyag vastagsága) alapján igazolta, de megerósítette vékonycsiszolatos és stabilizotópos vizsgálatokkal is. A vizsgálat során azonban több nagyvonalú egyszerúsítést is tett, feltételezve, hogy a sztilolitosodás során minden azonos rendú ciklustag között ugyanannyi karbonát oldódott fel, illetve egy ciklustag sem hiányzik teljesen feloldódás miatt. A terepi megfigyelések alapján a három szelvényben $65-68$ köteget sikerült elkülöníteni, melyekhez kb. 200-210 ezer éves periódusidőt rendelt. A periódusidőket úgy származtatta, hogy a rétegsorok biosztratigráfiai korreláció révén és a kalibrált geológiai időskála alapján valószínúsített képződési időtartamát elosztotta a kötegek számával. A jura időskála azonban azóta jelentős pontosításon ment át (PÁLFY et al. 2000, OGG et al. 2012), az eredmények revíziója a kora jura korszakok hosszának mai ismerete alapján is indokolt.

WILLIS et al. (1999a, b) a Pulai Alginiten végeztek ciklussztratigráfiai vizsgálatokat, és a boreális, valamint szubtrópusi pollenek mennyiségének változásából sikeresen mutatták ki a precesszió, a tengelyferdeség és a rövid excentricitás Milanković-ciklusait, továbbá szub-Milanković-tartományba esố változásokat is. Vizsgálatuk során elsősorban a csillagászati kalibráció módszerét alkalmazták a spektrálanalízis mellett, amihez ilyen fiatal üledékek esetében már 1999-ben is rendelkezésre álltak megfelelő módszerek és adatok.

NÁDOR et al. (2003) a magnetosztratigráfiai adatok szerint folyamatos és teljes pleisztocén folyóvízi rétegsort harántoló dévaványai (D-1) és vésztôi (V-1) fúrásokban a mágneses szuszceptibilitás és szemcseméret-eloszlás változásai alapján vélték felismerni a Milanković-ciklicitást. Korszerú matematikai módszerek alkalmazása nélkül, az oszcilláló jeleket egy mélytengeri fúrásból közölt $\delta^{18} \mathrm{O}$ referenciagörbével csupán vizuálisan korrelálva érveltek a tengelyferdeségi és az excentricitási periódusok kimutathatósága mellett. A fluviális üledékképződés éghajlati meghatározottságának támogatására az egyes magnetozónákba eső 
szuszceptibilitási maximumok számát és a környezetváltozásokat alátámasztó szedimentológiai, palinológiai és molluszka paleoökológiai adatokat használtak.

SACCHI \& MÜLLER (2004) az iharosberényi Ib-1 fúrásban, pannóniai üledékekben mutatták ki a precessziós és excentricitási ciklusokat elsősorban a szemcseméret változása alapján. Munkájuk során továbbfejlesztettek egy korábbi, ugyancsak az iharosberényi adatsoron alapuló tanulmányt (SPROVIERI et al. 2003). A vizsgálat során a korábbi spektrálanalízis-eredmények mellett egyéb rétegtani módszereket (szekvenciasztratigráfia, magnetosztratigráfia, biosztratigráfia), illetve egy akkoriban elég korszerú, a csillagászati kalibráción alapuló módszert használtak.

MüLLER et al. (2017) alsó jura, toarci rétegeket vizsgált a mecseki Réka-völgyben. Ciklussztratigráfiai vizsgálatokat a szerves anyagon mért $\delta^{13} \mathrm{C}$ jelében, illetve a rétegsor karbonáttartalmán végeztek. Ugyan a mért adatok egyértelmú ciklicitást mutattak, ezt nem lehetett minden kétséget kizáróan a Milanković-ciklusok bármelyikéhez kötni. Ezért a rövid excentricitással, tengelyferdeséggel és precesszióval számolva három lehetséges üledékképződési időtartamot adtak meg a toarci óceáni anoxikus esemény (TOAE, vagy más néven Jenkyns-esemény) hosszára, amelyek csökkenô sorban 1 millió év, 350 ezer év és 200 ezer év.

PÜSPÖKI et al. (2019) a Jászsági-medence kvarter folyóvízi rétegsorát harántoló jászladányi és hevesvezekényi fúrások ciklussztratigráfiai elemzésével egészítette ki a korábban is tanulmányozott (NÁDOR et al. 2003) Kőrös-medencei, dévaványai magfúrás vizsgálatát. A mágneses szuszceptibilitás mellett a jászsági fúrómagokon az üledék színét és fajlagos ellenállását is felhasználták a spektrálanalízishez. A multitaper módszerrel elóállított teljesítményspektrumokat a La2004 csillagászati modell alapján várható, illetve kínai löszszelvényeken kimutatott frekvenciákhoz próbálták illeszteni. Bár a 100 ezer éves excentricitást kimutatni vélték, a viszonylag alacsony teljesítményértékek alapján jogosan vetik fel a folyóvízi üledékes rendszer szabályostól eltérő viselkedését.

MARos et al. (2020) az ibafai Ib-4 jelú fúrás alsó triász Jakabhegyi Homokkő Formációt harántoló szakaszát vizsgálták. Magszkenneléssel lemez-, illetve rétegvastagság, dőlésirány, valamint dőlésszög adatsorokat állítottak elő. Ezekben az adatsorokban vizuálisan különböző rendú, dmskálájútól egészen $8 \mathrm{~m}$ vastagságig terjedő ciklusokat ismertek fel. Vizsgálatukat geomatematikai ciklicitáselemzéssel is kiegészítették, mely során hibakorrigált LombScargle periodicitás vizsgálatot használtak. Ennek segítségével sikerült kimutatniuk egy 1,3 m és egy 4,5 m periódussal rendelkező ciklust, azonban ezek ismert Milankovićciklusokhoz kapcsolására, valamint további következtetések levonására nem vállalkoztak.

\section{Nemzetközi kitekintés}

Az alábbiakban néhány kiválasztott, földtörténeti sorrendben röviden bemutatott esettanulmány segítségével szemléltetjük a korszerú ciklussztratigráfia jelentőségét. Az idézett tanulmányok nemcsak fontos lépést jelentettek a tudományág fejlődésében, de rávilágítanak az asztrokronológia növekvő szerepére is a földtörténeti időskála pontosításában, továbbá a csillagászati kényszer fontosságára a Föld bonyolult éghajlati rendszerének múködésében és az éghajlati tényezők meghatározó szerepére a különböző üledékes rendszerekben.

A Déli-Alpokban, a Dolomitokban található középső triász Latemar-platform régóta fontos ciklussztratigráfiai tanulmányok tárgyát képezi, és az egymásnak ellentmondó eredmények heves vitákat váltottak ki. A karbonátplatform képződési idejére vonatkozó asztrokronológiai és a biosztratigráfiai, illetve radiometrikus adatok jelentôsen eltértek egymástól, ami sokak szemében megkérdőjelezte a ciklussztratigráfia megbízhatóságát. A Latemar szembeötlő, méterskálájú peritidális ciklusait az elsô ciklussztratigráfiai vizsgálatok (GOLDHAMMER et al. 1987, 1990; HiNNOV \& GoldHAMMER 1991; PRETO et al. 2001) a precesszióhoz kapcsolták, és így a teljes platform képződési idejét 9-12 millió éves időtartamúnak tartották. Ezzel szemben a karbonátos rétegsor vulkanoklasztit közbetelepüléseinek cirkon U-Pb koradatai legfeljebb néhány millió éves időtartamot jeleztek (BRACK et al. 1996, MundiL et al. 2003). Az ellentmondást az okozta, hogy a korai ciklussztratigráfiai vizsgálatokhoz még nem állt rendelkezésére megfelelő kvantitatív módszer az egyes felismert ciklusok ismert periódusidejú ciklusokhoz kapcsolására (ZüHLKE et al. 2003). KENT et al. (2004) később igazolta, hogy a korábban precessziósnak vélt ciklus valójában egy kb. 1,7 ezer éves szub-Milanković ciklus, míg az addig ismeretlen eredetûnek és kb. 200 ezer éves periódusúnak tartott ciklus valójában precessziós eredetú. A sikeres párosítás után kimutathatóvá vált a rövid és a hosszú excentricitás is. Az új eredmények alapján a Latemar-platform rétegsorának lerakódása kb. 800 ezer évet vett igénybe, mely immár összhangban van a radiometrikus korokkal, illetve az integrált magnetosztratigráfiai és biosztratigráfiai eredményekkel is.

Szintén klasszikus ciklussztratigráfiai tanulmányok színtere az Észak-Amerika keleti partvidékén húzódó Newark-medence. A triász végén és jura elején ez az egykori rift medence az Egyenlítőhöz közel helyezkedett el. Rétegsora zömmel tavi üledékekből áll, a ciklicitás az egykori tó vízszintváltozásaihoz kapcsolódóan az üledékrétegek színének változásában is megfigyelhető (OLSEN \& KENT 1996, OLSEN et al. 1999). A kifejezetten szedimentológiai és ciklussztratigráfiai vizsgálatok céljából mélyített, egymással pontosan összeilleszthető mélyfúrási rétegsorok, kiegészítve a szomszédos, minden tekintetben hasonló Hartford-medence adataival (KENT \& OLSEN 2008, KENT et al. 2017) magukba foglalják a teljes felsô triászt és legalsó jurát. Ezáltal az egyik leghosszabb ciklussztratigráfiai szempontból vizsgált folytonos szelvényt és az abból származtatott csillagászati korskálát jelentik (HinNov \& HiLGEN 2012). A NewarkHartford-medence rétegsorán nagy felbontású magnetosztratigráfiai vizsgálatokat is végeztek, az integrált eredményekből csillagászati kalibrációjú pólusátfordulási skála (Astronomical Polarity Time Scale, APTS) is készült, meg- 
teremtve a globális korreláció lehetőségét tengeri szelvényekkel is (KENT et al. 2017). A Colorado-platón mélyült, hasonló korú rétegsorokat harántoló fúrások vizsgálati eredményeivel összehasonlítva megnyílni látszik az út a Naprendszer kaotikus viselkedéséből származó kb. 50 millió éves korlát áttörésére is, amennyiben a csillagászati modell helyett empirikus úton, jól megőrződött ciklusos rétegsorok vizsgálata alapján kiszámíthatóak a 405 ezer éves hosszú excentricitásnál kevésbé állandó ciklusok periódusidői is (OLSEN et al. 2019).

A kainozoikum ciklussztratigráfiája számára a csillagászati modell elérhetősége mellett a mélytengeri fúrómagok vizsgálatának lehetôsége is döntő jelentôségú. WESTERHOLD et al. (2020) tanulmánya széles nemzetközi összefogás keretében az egész kainozoikum legjobb bentosz foraminifera stabilizotóp-adatsoraiból $\left(\delta^{13} \mathrm{C}\right.$ és $\left.\delta^{8} \mathrm{O}\right)$ megalkotott új kompozit szelvényt ismertet (9. ábra). A kompozit szelvényen végzett ciklussztratigráfiai vizsgálatok alapján a paleocén-eocén szakaszra \pm 100 ezer, az oligocén-középsőmiocén szakaszra \pm 50 ezer, a késő-miocén és fiatalabb szakaszra pedig \pm 10 ezer éves hibahatárral hoztak létre korskálát. A rendkívüli hosszúságú és pontosságú korskála megalkotásán túl jellemezték a paleoklíma csillagászati kényszer által vezérelt változásait a kainozoikum során. A sarki jég térfogata és a légköri $\mathrm{CO}_{2}$ koncentrációja alapján négy különböző klímaállapotba (üvegház - hothouse, melegház warmhouse, hútőház - coolhouse, jégkorszak - icehouse) sorolták a kainozoikum egyes szakaszait. Kimutatták, hogy üvegház vagy melegház állapotban az éghajlat sokkal kiszámíthatóbban viselkedik, azaz sokkal egyértelmúbben reagál a Milanković-ciklusok jelentette csillagászati kényszerre, mint hútôház állapotban vagy jégkorszak idején.

Végül LiSIECKI \& RAYMO (2005) nagy jelentôségú munkájának ismertetésével kanyarodhatunk vissza a Milanković-ciklusok bölcsőjéhez, vagyis a plio-pleisztocén eljegesedés ciklikusságának vizsgálatához. Összesen 57 kiválasztott mélytengeri fúrómag bentosz foraminiferáinak $\delta^{18} \mathrm{O}$ adataiból hoztak létre olyan kompozit szelvényt, melyet az általuk a besugárzási görbe alapján előállított, a sarki jégsapka térfogatváltozásait tükröző célgörbével kalibráltak. A negyedidőszak rétegtanában mára elsőrendú jelentőségú tengeri izotópos szakaszokat (Marine Isotope Stages, MIS) sikerrel terjesztették ki a pliocén kezdetéig, 5,3 millió évre visszamenően, újból és meggyőzően igazolva az eljegesedések és a Milanković-ciklusok kapcsolatát.

\section{Összefoglalás}

Noha a rétegtan a geológia egyik legkorábban kialakult tudományága, fejlődése új módszereknek köszönhetően az elmúlt évtizedekben ismét lendületet vett. Az egyik leglátványosabban fejlődő terület a ciklussztratigráfia és asztrokronológia, melyek áttekintésére vállalkoztunk. Éppen 100 évvel ezelőtt fektette le Milutin MiLANKOvić annak az elméletnek a matematikai alapjait, amely a pleisztocén jégkorszak ismétlődő eljegesedéseit a Föld csillagászati pályaelemeinek periodikus változásai által vezérelt éghajlatváltozásokhoz kötötte. Azóta sokrétú bizonyítást nyert a Milanković-ciklusok, a precesszió, a tengelyferdeség és az excentricitás periodikus változásai által a besugárzás ingadozásából fakadó egykori klímaváltozások nyomainak megőrződése az üledékes kőzetek rétegsoraiban, nem csupán a legutolsó jégkorszak idején.

A paleoklíma indikátorainak egyre bővülő tárháza segítségével, litológiai, paleontológiai, fizikai és geokémiai adatsorok vizsgálata révén ciklusosnak bizonyultak olyan, nagyon különböző környezetekben keletkezett rétegsorok is, melyekról ez szabad szemmel nem állapítható meg. Az idősorelemzés matematikai módszerei rohamosan fejlődtek az elmúlt évtizedekben, széles körú alkalmazásukat pedig a számítástechnika forradalma tette lehetővé. Elterjedten használt protokollok állnak rendelkezésre az adatsorok előkészítésére, a gyors Fourier-transzformáció segítségével elvégzett spektrálanalízisre, majd az eredmények ábrázolására teljesítményspektrum és spektrogram segítségével. Az értelmezés során a meghatározott megbízhatósági szinteket meghaladó frekvenciacsúcsok periódusainak aránya ismeretében azonosíthatjuk a Milanković-ciklusokat. Az utolsó kb. 50 millió évre megbízható csillagászati modell segítségével végezhetô kalibráció, de az idősebb rétegsorokban a Naprendszer kaotikus viselkedése miatt csak a hosszú excentricitási ciklus 405 ezer éves periódusa megbízható. Mindazonáltal a jel szúrése után tetszőleges korú vizsgált szelvényhez készíthető lebegő korskála. A ciklussztratigráfiai elemzés többek között a közelmúltban fejlesztett, felhasználóbarát Acycle szoftver segítségével, belátható mértékủ tanulási folyamat után speciális előképzettség nélkül is elvégezhetô.

A nemzetközi szakirodalomban exponenciálisan nő a ciklussztratigráfiai tanulmányok száma. Ezek egyik fő célja az asztrokronológia, a rétegsorok keletkezési időtartamának
A

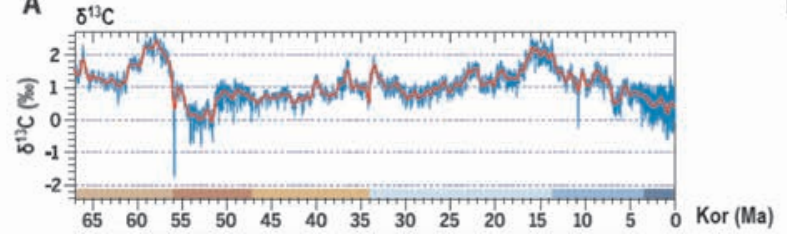

B

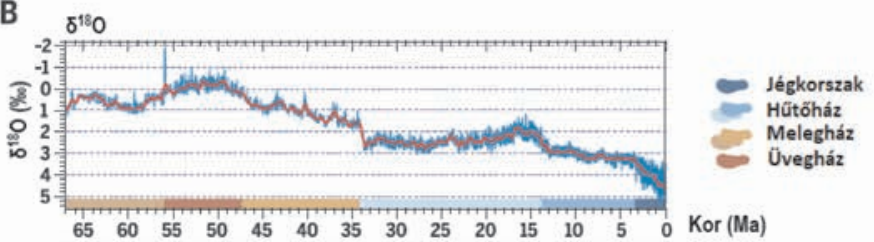

9. ábra. A kainozoikum klímaállapot-változásai asztrokronológiai kormodellre illesztett mélytengeri bentosz $\delta^{13} \mathrm{C}(\mathrm{A})$ és $\delta^{18} \mathrm{O}(\mathrm{B})$ kompozit adatsorok alapján. (WESTERHOLD et al. 2020 alapján)

Figure 9. Changes of Cenozoic climate states based on an astronomically dated composite of deep-sea benthic foraminifera $\delta^{13} C(A)$ és $\delta^{18} O(B)$ data. $(B a s e d$ on WESTERHOLD et al. 2020) 
meghatározása. Más rétegtani módszerekkel kombinálva ennek egyre növekvő szerepe van a földtörténeti időskála mind pontosabb kalibrálásában. A kormodellek megalkotása mellett hasonlóan fontos a ciklussztratigráfia szerepe a paleoklíma-kutatásban is. Ezek a kutatások egyben hozzájárultak az üledékképződési rendszerek klimatikusan meghatározott változásainak jobb megértéséhez is.

Hazánkban a 20. század derekán MiLANKOVIĆ kortársa, BACSÁK György sokat tett az elmélet fejlődéséért és elfogadtatásáért, hatásának köszönhetőek az első magyarországi geológiai alkalmazások is. Ezeket szórványosan követték továbbiak, a szemlénkben ismertetett korszerú módszertannal mindeddig csak két tanulmányban találkozhatunk. Abban a reményben foglaltuk össze a módszer alapjait, használatának lépéseit és geológiai alkalmazásait, hogy ezzel elősegíthetjük a modern ciklussztratigráfia és asztrokronológia hazai elterjedését. Egyrészt a felsorolt hazai példák némelyikének korszerú újravizsgálata új eredményekkel kecsegtet, másrészt számos további magyarországi képződmény ciklicitásának vizsgálatából várhatók jelentős, új rétegtani eredmények.

\section{Köszönetnyilvánítás}

Köszönjük SzTANó Orsolya biztatását ennek a magyar nyelvú összefoglaló tanulmánynak az elkészítésére és hasznos szerkesztői megjegyzéseit. Mathieu MARTINEz (Université de Rennes) segítsége nélkülözhetetlen volt az itt ismertetett módszerek használatának elsajátításához. Köszönet illeti HAAs Jánost és KovÁCs Józsefet bírálóként tett építô kritikai megjegyzéseikért. A kutatást az Európai Unió és Magyarország támogatta az Európai Regionális Fejlesztési Alap társfinanszírozásában a GINOP-2.3.2.-15-2016-00009 azonosítószámú 'IKER' pályázatban, valamint az NKFIH OTKA K135309 pályázatban. Ez a tanulmány az MTAMTM-ELTE Paleontológiai Kutatócsoport 336. publikációja.

\section{Irodalom — References}

AdHÉmar, J. 1842: Révolutions de la mer. — Carilion-Goeury \& V. Dalmont, Paris, 112 p.

BАCSÁK G. 1940: Az interglaciális korszakok értelmezése. — Az Idójárás 44/1-2, 3-4, 5-6, 8-16, 62-69, 105-108.

BACSÁK G. 1954: A pliocén és a pleisztocén az égi mechanika megvilágításában. — Földtani Közlöny 85/1, 70-105.

Bajnai, D., PÁlfy, J., Martinez, M., Price, G. D., Nyerges, A. \& FốZY, I. 2017: Multi-proxy record of orbital-scale changes in climate and sedimentation during the Weissert Event in the Valanginian Bersek Marl Formation (Gerecse Mts., Hungary). - Cretaceous Research 75, 45-60. https://doi.org/10.1016/j.cretres.2017.02.021

BAlOG, A., HAAS, J., READ, J. F. \& CORUH, C. 1997: Shallow marine record of orbitally forced cyclicity in a Late Triassic carbonate platform, Hungary. - Journal of Sedimentary Research 67/4, 661-675. https://doi.org/10.1306/d426860d-2b26-11d7$8648000102 \mathrm{c} 1865 \mathrm{~d}$

Berger, A. \& Loutre, M. F. 1994: Precession, eccentricity, obliquity, insolation and paleoclimates. — In: DuPLESSY, J.-C. \& SPYRIDAKIS, M.-T. (eds): Long-term Climatic Variations. NATO ASI Series 22. Springer Berlin, Heidelberg, 107-151. https://doi.org/ 10.1007/978-3-642-79066-9_5

Blackman, R. B. \& Tukey, J. W. 1958: The Measurement of Power Spectra from the Point of View of Communication Engineering. Dover Publications, $190 \mathrm{p}$.

Bloomfield, P. 2000: Fourier Analysis of Time Series: An Introduction (2. ed.). - Wiley \& Sons Ltd., 272 p.

Boer, P. L. De \& Smith, D. G. (eds) 1994: Orbital Forcing and Cyclic Sequences. — In: Special Publication of The International Association of Sedimentologists 19. Blackwell Scientific Publications. 559 p. https://doi.org/10.1002/9781444304039

Boulila, S. 2019: Coupling between Grand cycles and Events in Earth's climate during the past 115 million years. — Scientific Reports 9, 327. https://doi.org/10.1038/s41598-018-36509-7

Brack, P., Mundil, R., Oberli, F., Meier, M. \& Rieber, H. 1996: Biostratigraphic and radiometric age data question the Milankovitch characteristics of the Latemar cycles (Southern Alps, Italy). — Geology 24/4, 371-375. https://doi.org/10.1130/00917613(1996)024<0371:Baradq >2.3.Co;2

COOLEY, J. W. \& TUKEY, J. W. 1965: An algorithm for the machine calculation of complex Fourier series. — Mathematics of Computation 19, 297-301. https://doi.org/10.1090/S0025-5718-1965-0178586-1

Croll, J. 1864: On the physical cause of the change of climate during geological epochs. - The London, Edinburgh, and Dublin Philosophical Magazine and Journal of Science 28/187, 121-137. https://doi.org/10.1080/14786446408643733

CVijanovic, I., Lukovic, J. \& BEGG, J. D. 2020: One hundred years of Milanković cycles. — Nature Geoscience 13, 524-525. https:// doi.org/10.1038/s41561-020-0621-2

D’Argenio, B., Fischer, A. G., Premoli Silva, I., Weissert, H. \& Ferreri, V. (eds) 2004: Cyclostratigraphy: Approaches and Case Histories. - In: SEPM Special Publication 81. SEPM (Society for Sedimentary Geology). Tulsa, Oklahoma, USA, 311 p. https:// doi.org/10.2110/pec.04.81

Einsele, G., RicKen, W. \& SeILACHER, A. 1991: Cycles and Events in Stratigraphy. — Springer-Verlag, 995 p.

FisCHER, A. G. 1964: The Lofer cyclothems of the alpine Triassic. — Kansas Geological Survey Bulletin 169, 107-149. 
Fischer, A. G., De Boer, P. L. \& Premoli Silva, I. 1990: Cyclostratigraphy. — In: Ginsburg, R. N. \& Beaudoin, B. (eds): Cretaceous Resources, Events and Rhythms: Background and Plans for Research. Nato ASI Series C 304. Springer Dordrecht, $139-172$. https://doi.org/10.1007/978-94-015-6861-6_8

FOGARASI, A. 1995: Ciklussztratigráfiai vizsgálatok a gerecsei krétában: előzetes eredmények (Cretaceous cyclostratigraphy of Gerecse Mts: Preliminary results). —Általános Földtani Szemle 27, 43-58.

GiLBERT, G. K. 1895: Sedimentary measurement of Cretaceous time. — The Journal of Geology 3/2, 121-127. https://doi.org/10.1086/ 607150

Goldhammer, R. K., DunN, P. A. \& Hardie, L. A. 1987: High frequency glacio-eustatic sealevel oscillations with Milankovitch characteristics recorded in Middle Triassic platform carbonates in northern Italy. — American Journal of Science 287/9, 853-892. https:// doi.org/10.2475/ajs.287.9.853

Goldhammer, R. K., Dunn, P. A. \& HARdie, L. A. 1990: Depositional cycles, composite sea-level changes, cycle stacking patterns, and the hierarchy of stratigraphic forcing: Examples from Alpine Triassic platform carbonates. _ Geological Society of America Bulletin 102/5, 535-562. https://doi.org/10.1130/0016-7606(1990)102<0535:Dccslc >2.3.Co;2

HAAS, J., Ó. KovÁCS, L. \& TARDI-FILÁCZ, E. 1994: Orbitally forced cyclical changes in the quantity of calcareous and siliceous microfossils in an upper Jurassic to lower Cretaceous pelagic basin succession, Bakony Mountains, Hungary. — Sedimentology 41/4, 643653. https://doi.org/10.1111/j.1365-3091.1994.tb01415.x

Hammer, $\varnothing . \&$ HarPer, D. A. T. 2006: Paleontological Data Analysis. - Blackwell Publishing, 351 p. https://doi.org/10.1002/ 9780470750711

HAYS, J. D., IMBRIE, J. \& SHACKLETON, N. J. 1976: Variations in the Earth's orbit: Pacemaker of the ice ages. — Science 194/4270, 1121_ 1132. https://doi.org/10.1126/science.194.4270.1121

Hilgen, F. J. 2010: Astronomical dating in the 19th century. — Earth-Science Reviews 98/1-2, 65-80. https://doi.org/10.1016/ j.earscirev.2009.10.004

Hinnov, L. A. 2013: Cyclostratigraphy and its revolutionizing applications in the earth and planetary sciences. — Geological Society of America Bulletin 125/11-12, 1703-1734. https://doi.org/10.1130/B30934.1

Hinnov, L. A. \& Goldhammer, R. K. 1991: Spectral analysis of the Middle Triassic Latemar Limestone. — Journal of Sedimentary Research 61/7, 1173-1193. https://doi.org/10.1306/d4267861-2b26-11d7-8648000102c1865d

Hinnov, L. A. \& Hilgen, F. J. 2012: Cyclostratigraphy and Astrochronology. — In: Gradstein, F. M., OgG, J. G., Schmitz, M. D. \& OGG, G. M. (eds): The Geologic Time Scale 2012. Elsevier, 63-83. https://doi.org/10.1016/B978-0-444-59425-9.00004-4

Imbrie, J. \& ImbriE, K. P. 1979: Ice Ages: Solving the Mystery. — Enslow Publishers, 224 p.

IMBRIE, J. \& IMBRIE, J. Z. 1980: Modeling the climatic response to orbital variations. — Science 207/4434, 943-953. https://doi.org/ 10.1126/science.207.4434.943

Juhász, E., Ó. Kovács, L., Müller, P., Tóth-Makk, Á., Phillips, L. \& Lantos, M. 1997: Climatically driven sedimentary cycles in the Late Miocene sediments of the Pannonian Basin, Hungary. — Tectonophysics 282/1-4, 257-276. https://doi.org/10.1016/s00401951(97)00222-9

Juhász, E., Phillips, L., Müller, P., Ricketts, B., Tóth-Makk, Á., Lantos, M. \& Ó. Kovács, L. 1999: Late Neogene sedimentary facies and sequences in the Pannonian Basin, Hungary. - In: Durand, B., Jolivet, L., Horváth, F. \& Séranne, M. (eds): The Mediterranean Basins: Tertiary Extension within the Alpine Orogen. Geological Society, London, Special Publications 156, Geological Society London, UK, 335-356. https://doi.org/10.1144/gs1.Sp.1999.156.01.16

KenNeDY, J. A. \& BRASSELl, S. C. 1992: Molecular records of twentieth-century El Niño events in laminated sediments from the Santa Barbara basin. - Nature 357, 62-64. https://doi.org/10.1038/357062a0

Kent, D. V., Muttoni, G. \& Brack, P. 2004: Magnetostratigraphic confirmation of a much faster tempo for sea-level change for the Middle Triassic Latemar platform carbonates. — Earth and Planetary Science Letters 228/3-4, 369-377. https://doi.org/10.1016/ j.eps1.2004.10.017

KENT, D. V. \& OlsEn, P. E. 2008: Early Jurassic magnetostratigraphy and paleolatitudes from the Hartford continental rift basin (eastern North America): Testing for polarity bias and abrupt polar wander in association with the central Atlantic magmatic province. Journal of Geophysical Research 113, B06105. https://doi.org/10.1029/2007jb005407

Kent, D. V., Olsen, P. E. \& Muttoni, G. 2017: Astrochronostratigraphic polarity time scale (APTS) for the Late Triassic and Early Jurassic from continental sediments and correlation with standard marine stages. — Earth-Science Reviews 166, 153-180. https:// doi.org/10.1016/j.earscirev.2016.12.014

Kotelnikov, V. A. 1933: On the carrying capacity of the ether and wire in telecommunications. — Proceedings of the first All-Union Conference on the technological reconstruction of the communications sector and the development of low-current engineering.

Laskar, J., Robutel, P., Joutel, F., Gastineau, M., Correia, A. C. M. \& Levrard, B. 2004: A long-term numerical solution for the insolation quantities of the Earth. — Astronomy \& Astrophysics 428/1, 261-285. https://doi.org/10.1051/0004-6361:20041335

Laskar, J., Fienga, A., Gastineau, M. \& Manche, H. 2011: La2010: A new orbital solution for the long-term motion of the Earth. Astronomy \& Astrophysics 532, A89. https://doi.org/10.1051/0004-6361/201116836

LEES, J. M. \& PARK, J. 1995: Multiple-taper spectral analysis: A stand-alone C-subroutine. — Computers \& Geosciences 21/2, 199-236. https://doi.org/10.1016/0098-3004(94)00067-5

Li, M., Hinnov, L. \& Kump, L. 2019a: Acycle: Time-series analysis software for paleoclimate research and education. — Computers \& Geosciences 127, 12-22. https://doi.org/10.1016/j.cageo.2019.02.011

Li, M., Huang, C., OgG, J., Zhang, Y., Hinnov, L., Wu, H., Chen, Z.-Q. \& Zou, Z. 2019b: Paleoclimate proxies for cyclostratigraphy: Comparative analysis using a Lower Triassic marine section in South China. — Earth-Science Reviews 189, 125-146. https://doi.org/ 10.1016/j.earscirev.2019.01.011 
LisIECKI, L. E. \& RAYMO, M. E. 2005: A Pliocene-Pleistocene stack of 57 globally distributed benthic $\delta^{18}$ O records. — Paleoceanography 20/1, PA1003. https://doi.org/10.1029/2004pa001071

LomB, N. R. 1976: Least-squares frequency-analysis of unequally spaced data. - Astrophysics and Space Science 39/2, 447-462. https://doi.org/10.1007/Bf00648343

MAJOR G. 2006: A Milankovics-Bacsák elmélet és az éghajlatváltozások. — Légkör 51/Különszám, 20-23.

MANN, M. E. \& LEES, J. M. 1996: Robust estimation of background noise and signal detection in climatic time series. — Climatic Change 33/3, 409-445. https://doi.org/10.1007/BF00142586

Maros G., Szabadosné Sallay E., ÁdÁmné Incze S., Hatvani I. G., Palotás K., Kovács J., Gyenis Á., Gróf G., PÁsztor S., AndRÁssy L., Mara J., Vihar L. \& Szongoth G. 2020: Az ImaGeo magszkennelés módszerei egy mecseki fúrás nagyfelbontású értelmezésének példáján. — Földtani Közlöny 150/1, 81-102. https://doi.org/10.23928/foldt.kozl.2020.150.1.81

MARTINEZ, M. 2018: Mechanisms of preservation of the eccentricity and longer-term Milankovitch cycles in detrital supply and carbonate production in hemipelagic marl-limestone alternations. — In: MonTENARI, M. (ed.): Stratigraphy \& Timescales 3, 189-218. https:// doi.org/10.1016/bs.sats.2018.08.002

MartineZ, M. \& Dera, G. 2015: Orbital pacing of carbon fluxes by a approximately 9-My eccentricity cycle during the Mesozoic. Proceedings of the National Academy of Sciences of the United States of America 112/41, 12604-12609. https://doi.org/10.1073/ pnas.1419946112

Martinez, M., Deconinck, J.-F., Pellenard, P., Riquier, L., Company, M., Reboulet, S. \& Moiroud, M. 2015: Astrochronology of the Valanginian-Hauterivian stages (Early Cretaceous): Chronological relationships between the Paraná-Etendeka large igneous province and the Weissert and the Faraoni events. - Global and Planetary Change 131, 158-173. https://doi.org/10.1016/ j.gloplacha.2015.06.001

Martinez, M., Kotov, S., De Vleeschouwer, D., Pas, D. \& PÄlike, H. 2016: Testing the impact of stratigraphic uncertainty on spectral analyses of sedimentary series. — Climate of the Past 12/9, 1765-1783. https://doi.org/10.5194/cp-12-1765-2016

Martínez-Braceras, N., Payros, A., Miniati, F., Arostegi, J., Franceschetti, G. \& Reijmer, J. 2017: Contrasting environmental effects of astronomically driven climate change on three Eocene hemipelagic successions from the Basque-Cantabrian Basin. Sedimentology 64/4, 960-986. https://doi.org/10.1111/sed.12334

MEYERS, S. R. 2012: Seeing red in cyclic stratigraphy: Spectral noise estimation for astrochronology. — Paleoceanography 27/3, PA3228. https://doi.org/10.1029/2012PA002307

MEYERS, S. R. 2014: Astrochron: An R package for astrochronology (0.9). https://cran.r-project.org/package=astrochron

Meyers, S. R. \& SAGEMAN, B. B. 2007: Quantification of deep-time orbital forcing by average spectral misfit. — American Journal of Science 307/5, 773-792. https://doi.org/10.2475/05.2007.01

Milankovich, M. 1920: Théorie Mathématique des Phénomènes Thermiques Produits Par la Radioation Solaire. — Gauthier-Villars, Paris, $340 \mathrm{p}$.

MilanKovich, M. 1941: Kanon der Erdbestrahlungen und seine Anwendung auf das Eiszeitenproblem. — Königlich Serbische Akademie, Belgrade, $626 \mathrm{p}$.

Mundil, R., Zühlke, R., Bechstädt, T., Peterhänsel, A., Egenhoff, S. O., Oberli, F., Meier, M., Brack, P. \& Rieber, H. 2003: Cyclicities in Triassic platform carbonates: Synchronizing radio-isotopic and orbital clocks. - Terra Nova 15/2, 81-87. https:// doi.org/10.1046/j.1365-3121.2003.00475.x

Müller, T., Price, G. D., Bajnai, D., Nyerges, A., Kesjár, D., Raucsik, B., Varga, A., Judik, K., Fekete, J., May, Z. \& Pálfy, J. 2017 : New multiproxy record of the Jenkyns Event (also known as the Toarcian Oceanic Anoxic Event) from the Mecsek Mountains (Hungary): Differences, duration and drivers. — Sedimentology 64/1, 66-86. https://doi.org/10.1111/sed.12332

NÁDOR, A., LANTOS, M., TótH-MAKK, Á. \& THAMó-Bozsó, E. 2003: Milankovitch-scale multi-proxy records from fluvial sediments of the last 2.6 Ma, Pannonian Basin, Hungary. — Quaternary Science Reviews 22/20, 2157-2175. https://doi.org/10.1016/S0277-3791(03)00134-3

NAISH, T. \& KAMP, P. J. J. 1997: Sequence stratigraphy of sixth-order (41 k.y.) Pliocene-Pleistocene cyclothems, Wanganui basin, New Zealand: A case for the regressive systems tract. — Geological Society of America Bulletin 109/8, 978-999. https://doi.org/10.1130/ 0016-7606(1997)109<0978:Ssosok>2.3.Co;2

NYQUIST, H. 1928: Certain topics in telegraph transmission theory. — Transactions of the American Institute of Electrical Engineers 47/2, 617-644. https://doi.org/10.1109/T-AIEE.1928.5055024

OgG, J. G. 2012: Triassic. — In: Gradstein, F. M., OgG, J. G., Schmitz, M. D. \& OgG, G. M. (eds): The Geologic Time Scale 2012. Elsevier, 681-730. https://doi.org/10.1016/B978-0-444-59425-9.00025-1

OgG, J. G., Hinnov, L. A. \& Huang, C. 2012: Jurassic. — In: Gradstein, F. M., OGG, J. G., Schmitz, M. D. \& OgG, G. M. (eds): The Geologic Time Scale 2012. Elsevier, 731-791. https://doi.org/10.1016/B978-0-444-59425-9.00026-3

Olsen, P. E. \& Kent, D. V. 1996: Milankovitch climate forcing in the tropics of Pangaea during the Late Triassic. — Palaeogeography, Palaeoclimatology, Palaeoecology 122/1-4, 1-26. https://doi.org/10.1016/0031-0182(95)00171-9

Olsen, P. E., Shackleton, N. J., McCave, I. N., Weedon, G. P. \& Kent, D. V. 1999: Long-period Milankovitch cycles from the Late Triassic and Early Jurassic of eastern North America and their implications for the calibration of the Early Mesozoic time-scale and the long-term behaviour of the planets. - Philosophical Transactions of the Royal Society of London. Series A: Mathematical, Physical and Engineering Sciences 357/1757, 1761-1786. https://doi.org/10.1098/rsta.1999.0400

Olsen, P. E., Laskar, J., Kent, D. V., Kinney, S. T., Reynolds, D. J., Sha, J. \& Whiteside, J. H. 2019: Mapping Solar System chaos with the Geological Orrery. - Proceedings of the National Academy of Sciences of the United States of America 116/22, 10664-10673. https://doi.org/10.1073/pnas.1813901116

PÁlfy, J., Smith, P. L. \& Mortensen, J. K. 2000: A U-Pb and ${ }^{40} \mathrm{Ar} /{ }^{39} \mathrm{Ar}$ time scale for the Jurassic. — Canadian Journal of Earth Sciences 37/6, 923-944. https://doi.org/10.1139/e00-002 
Percival, D. B. \& Walden, A. T. 1993: Spectral Analysis for Physical Applications: Multitaper and Conventional Univariate Techniques. - Cambridge University Press, 612 p. https://doi.org/10.1017/CBO9780511622762

Preto, N., Hinnov, L. A., Hardie, L. A. \& De Zanche, V. 2001: Middle Triassic orbital signature recorded in the shallow-marine Latemar carbonate buildup (Dolomites, Italy). — Geology 29/12, 1123-1126. https://doi.org/10.1130/0091-7613(2001)029<1123:Mtosri>2.0.Co;2

Püspöki, Z., Fogarassy Pummer, T., Thamó Bozsó, E., Berényi, B., Cserkész Nagy, Á., Szappanos, B., Márton, E., Lantos, Z., NÁDOR, A., Fancsik, T., Stercel, F., Tóth Makk, Á., McIntosh, R. W., Szőcs, T. \& Faragó, E. 2019: High resolution stratigraphy of a Quaternary fluvial deposit based on magnetic susceptibility variations (Jászság Basin, Hungary). — Boreas 49/1, 181-199. https:// doi.org/10.1111/bor.12412

ReZESSY A. 1998: A Pisznicei Mészkő ciklussztratigráfiai vizsgálata gerecsei szelvényeken. — Földtani Közlöny 128/2-3, 297-320.

SACCHI, M. \& MÜLlER, P. 2004: Orbital cyclicity and astronomical calibration of the Upper Miocene continental succession cored at Iharosberény-I well site, western Pannonian basin, Hungary. — In: D’ARgenio, B., Fischer, A. G., Premoli Silva, I., WeisSERT, H. \& Ferreri, V. (eds): Cyclostratigraphy: Approaches and Case Histories. SEPM Special Publication 81. SEPM (Society for Sedimentary Geology) Tulsa, Oklahoma, USA, 275-294. https://doi.org/10.2110/pec.04.81.0275

SCARGLE, J. D. 1982: Studies in astronomical time series analysis. II. Statistical aspects of spectral analysis of unevenly spaced data. Astrophysical Journal 263, 835-853. https://doi.org/10.1086/160554

SCHLAGER, W. 2005: Carbonate Sedimentology and Sequence Stratigraphy. - Concepts in Sedimentology and Paleontology 8, SEPM, 200 p. https://doi.org/10.2110/csp.05.08

SchwARZACHER, W. 1947: Über die sedimentäre Rhythmik des Dachsteinkalkes von Lofer. — Verhandlungen der Geologischen Bundesanstalt 1947, 175-188.

SCHWARZACHER, W. 1954: Die Großrhytmik des Dachsteinkalkes von Lofer. — Tschermaks mineralogische und petrographische Mitteilungen 4, 44-54. https://doi.org/10.1007/BF01140374

SCHWARZACHER, W. 1975: Sedimentation Models and Quantitative Stratigraphy. _ Developments in Sedimentology 19, Elsevier Science, 382 p. https://doi.org/10.1016/s0070-4571(08)x7020-7

SCHWARZACHER, W. 1992: Cyclostratigraphy and the Milankovitch Theory. — Developments in Sedimentology 52, Elsevier Science, 225 p.

SCHWARZACHER, W. \& HAAS, J. 1986: Comparative statistical analysis of some Hungarian and Austrian Upper Triassic peritidal carbonate sequences. - Acta Geologica Hungarica 29/3-4, 175-196.

Shannon, C. E. 1949: Communication in the presence of noise. - Proceedings of the IRE 37/1, 10-21. https://doi.org/10.1109/ JRPROC.1949.232969

Sinnesael, M., De Vleeschouwer, D., Zeeden, C., Batenburg, S. J., Da Silva, A.-C., De Winter, N. J., DinarČs-Turell, J., Drury, A. J., Gambacorta, G., Hilgen, F. J., Hinnov, L. A., Hudson, A. J. L., Kemp, D. B., Lantink, M. L., Laurin, J., Li, M., Liebrand, D., Ma, C., Meyers, S. R., Monkenbusch, J., Montanari, A., Nohl, T., Pälike, H., Pas, D., Ruhl, M., Thibault, N., Vahlenkamp, M., Valero, L., Wouters, S., Wu, H. \& Claeys, P. 2019: The Cyclostratigraphy Intercomparison Project (CIP): Consistency, merits and pitfalls. —Earth-Science Reviews 199, 102965. https://doi.org/10.1016/j.earscirev.2019.102965

Sprovieri, M., SACCHI, M. \& RoHLING, E. J. 2003: Climatically influenced interactions between the Mediterranean and the Paratethys during the Tortonian. - Paleoceanography 18/2, 1034. https://doi.org/10.1029/2001PA000750

Strasser, A., Pittet, B., Hillgartner, H. \& Pasquier, J.-B. 1999: Depositional sequences in shallow carbonate-dominated sedimentary systems: concepts for a high-resolution analysis. — Sedimentary Geology 128/3-4, 201-221. https://doi.org/10.1016/ S0037-0738(99)00070-6

Strasser, A., Hilgen, F. J. \& Heckel, P. H. 2007: Cyclostratigraphy concepts, definitions, and applications. — Newsletters on Stratigraphy 42/2, 75-114. https://doi.org/10.1127/0078-0421/2006/0042-0075

SZEDERKÉNYI T. 1963: Üledékképződési időszámítás a délmecseki szarmata rétegekben. — Földtani Közlöny 93/1, 54-62.

SzTANó, O. 1995: Palaeogeographic significance of tidal deposits: an example from an early Miocene Paratethys embayment, Northern Hungary. - Palaeogeography, Palaeoclimatology, Palaeoecology 113/2-4, 173-187. https://doi.org/10.1016/0031-0182(95)00054-p

THOMSON, D. J. 1982: Spectrum estimation and harmonic analysis. — Proceedings of the IEEE 70/9, 1055-1096. https://doi.org/10.1109/ PROC.1982.12433

Thomson, D. J. 1990: Quadratic-inverse spectrum estimates: applications to palaeoclimatology. — Philosophical Transactions of the Royal Society A: Mathematical, Physical and Engineering Sciences 332/1627, 539-597. https://doi.org/10.1098/rsta.1990.0130

Vail, P. R., Audemard, F., Bowman, S. A., Eisner, P. N. \& Perez-Cruz, C. 1991: The stratigraphic signatures of tectonics, eustacy and sedimentology - an overview. - In: Einsele, G., Ricken, W. \& SeIlacher, A. (eds): Cycles and Events in Stratigraphy. SpringerVerlag, 617-659.

WEEDON, G. 2003: Time-Series Analysis and Cyclostratigraphy: Examining stratigraphic records of environmental cycles. —Cambridge University Press, 276 p. https://doi.org/10.1017/CBO9780511535482

WeLCH, P. 1967: The use of fast Fourier transform for the estimation of power spectra: A method based on time averaging over short, modified periodograms. — IEEE Transactions on Audio and Electroacoustics 15/2, 70-73. https://doi.org/10.1109/tau.1967.1161901

Wendler, J. E., Wendler, I., Vogt, C. \& Kuss, J. 2016: Link between cyclic eustatic sea-level change and continental weathering: Evidence for aquifer-eustasy in the Cretaceous. - Palaeogeography, Palaeoclimatology, Palaeoecology 441/3, 430-437. https:// doi.org/10.1016/j.palaeo.2015.08.014

Westerhold, T., Marwan, N., Drury, A. J., Liebrand, D., Agnini, C., Anagnostou, E., Barnet, J. S. K., Bohaty, S. M., De Vleeschouwer, D., Florindo, F., Frederichs, T., Hodell, D. A., Holbourn, A. E., Kroon, D., Lauretano, V., Littler, K., Lourens, L. J., Lyle, M., Pälike, H., RÖHl, U., Tian, J., Wilkens, R. H., Wilson, P. A. \& ZaChos, J. C. 2020: An astronomically dated record of Earth's climate and its predictability over the last 66 million years. - Science 369/6509, 1383-1387. https://doi.org/ 10.1126/science.aba6853 
Westphal, H., Hilgen, F. \& Munnecke, A. 2010: An assessment of the suitability of individual rhythmic carbonate successions for astrochronological application. — Earth-Science Reviews 99/1-2, 19-30. https://doi.org/10.1016/j.earscirev.2010.02.001

WhitTAKeR, E. T. 1915: On the functions which are represented by the expansions of the interpolation-theory. — Proceedings of the Royal Society of Edinburgh 35, 181-194. https://doi.org/10.1017/S0370164600017806

Willis, K. J., Kleczkowski, A., Briggs, K. M. \& Gilligan, C. A. 1999a: The role of sub-Milankovitch climatic forcing in the initiation of the northern hemisphere glaciation. - Science 285/5427, 568-571. https://doi.org/10.1126/science.285.5427.568

Willis, K. J., KleCZKowsKi, A. \& Crowhurst, S. J. 1999b: 124,000-year periodicity in terrestrial vegetation change during the late Pliocene epoch. - Nature 397, 685-688. https://doi.org/10.1038/17783

ZeEBE, R. E. 2017: Numerical solutions for the orbital motion of the solar system over the past 100 Myr: Limits and new results. - The Astronomical Journal 154/5, 193. https://doi.org/10.3847/1538-3881/aa8cce

ZeEbe, R. E. \& LouRENS, L. J. 2019: Solar System chaos and the Paleocene-Eocene boundary age constrained by geology and astronomy. - Science 365/6456, 926-929. https://doi.org/10.1126/science.aax0612

Zeeden, C., Meyers, S. R., Lourens, L. J. \& Hilgen, F. J. 2015: Testing astronomically tuned age models. — Paleoceanography 30/4, 369-383. https://doi.org/10.1002/2014pa002762

Zeeden, C., Kaboth, S., Hilgen, F. J. \& Laskar, J. 2018: Taner filter settings and automatic correlation optimisation for cyclostratigraphic studies. - Computers \& Geosciences 119, 18-28. https://doi.org/10.1016/j.cageo.2018.06.005

ZÜHLKE, R., BECHSTÄDT, T. \& MUNDIL, R. 2003: Sub-Milankovitch and Milankovitch forcing on a model Mesozoic carbonate platform the Latemar (Middle Triassic, Italy). — Terra Nova 15/2, 69-80. https://doi.org/10.1046/j.1365-3121.2003.00366.x

Kézirat beérkezett: 2020. 09. 28. 